\title{
THE HEALTH OF AN URBAN COMMUNITY
}

\author{
BY \\ LILLI STEIN AND S. A. SKLAROFF \\ Department of Public Health and Social Medicine, University of Edinburgh
}

Present-day society urgently needs reliable measures, both local and national, of the health of the people. Declines in death rates undoubtedly indicate great improvements in public health in terms of survival, but do not necessarily represent equal declines in the numbers of the sick and the magnitude of their needs. More precise knowledge is needed of ailments and diseases in specific communities, as a factual basis to administer present services for the sick, to interpret local trends of morbidity, to enlarge the content of epidemiology and translate its findings into preventive measures, and to plan new services in changing conditions or newlydeveloping areas.

But this knowledge must be specified in precise terms. "Total" knowledge of a community is an abstract concept, in reality unattainable. Medicine does not deal with the total person, nor does public health administer the total community, but each selects certain features which to the doctor or administrator seem important.

In social medicine we must consider it important to seek knowledge concerning the preventable ill-health of communities in order that preventive action may be taken. Since prevention and the measurement of the preventable are aspects of a single process, and since the normal agencies of prevention are local, the laboratory of social medicine is the local community, and its interest is focussed on the social group rather than on individuals. The life and circumstances of the small community or "neighbourhood" are dominant influences on the health of the individual in an urban society. This small definable community we take to be the unit of research: and we judge as important those environmental factors which can foster or impair the life and well-being of the social group. We therefore select for investigation those aspects of social and health experience which relate particularly to the promotion of the health of the group in its own local environment.

\section{ORIGIN OF This STUDY}

No-one concerned with the health of the Scottish people can ignore the problem of respiratory tuberculosis in Scotland. It is generally accepted that tuberculosis, commonly referred to as a "social disease", has social causes and consequences; yet these are rarely investigated with the precision essential for firm conclusions from which preventive action can spring.

These social factors cannot be considered in isolation from the communal life of the whole group whose location and daily activities hold it together. The tuberculous are not a peculiar category in the population, to be found only in case-histories or in mortality records. 
Tuberculosis is not merely another disease with certain clinical implications. It is a part of the ill-health of the community, reducing working capacity and disrupting family life. But statistical analyses or studies of records seem to stop just at the point at which the day-to-day problems of the disease in relation to the whole community begin: such analyses are necessarily limited by recorded data. On the other hand, the follow-up of individual case-histories or the comparison of two systems of therapy does not yield knowledge which can be translated into preventive measures for the whole group. The necessary knowledge can only come from planned investigation of the social and medical circumstances of the whole group in which disease develops.

Moreover, investigations of sickness frequently have limitations other than those imposed upon them by records. Sickness is calculated in terms of hospital-treated persons or in averages found from claims for sickness benefit, or from interpretations of answers in sample surveys of the lay population. Each type of study commonly seems to indicate that other techniques give a different and therefore presumably less accurate picture. These differences are inherent in the data themselves: one set of records, collected for one specific purpose, naturally excludes any sickness which does not come into that category. Any single technique of enquiry yields data which, if isolated from the context in which they have meaning, give a one-sided description of group sickness experience.

This particular project of socio-medical research, arising from the problems of "social disease" and especially of tuberculosis, was influenced by the apparent limitations of aim and method of previous investigations. Thus our emphasis was placed on features commonly excluded, on group life and environment, on social and health experience, and on the circumstances and habits which might foster the spread of disease in a community in which infection is endemic. These aspects were selected according to their relevance to the incidence, spread, or control of disease in the community.

The group or groups studied were to be socially definable units. The whole group in its own environment was to be the object of investigation, not merely the categories of "diseased" against "controls". Moreover, the study was not to be based on one approach alone. If the sickness experience of the group were to be discovered, illness treated in hospital or sickness recorded in claims could not be separated from ailments felt and expressed by the members of the community.

\section{Objectives of This Study}

This investigation of a particular urban community within a large city was planned as a pre-pilot study for a long-term socio-medical research project. The group selected was one that had been re-housed some 16 years, having been removed from an overcrowded neighbouring area to a newly-built housing estate on the fringe of the city. The present population largely consists of members of the original families, and is generally recognized - both by its own members and by other people in all parts of the city - as a definable social unit.

The aspects of group life and conditions which could be studied in this pre-pilot enquiry had to be limited. The four main aspects of study selected as relevant to health were:
(i) housing occupancy,
(iii) food habits
(ii) general health experience,
(iv) leisure pursuits.

The last two are often publicly stated to be associated with disease, though evidence for such statements is not usually forthcoming.

The information obtained by various techniques of investigation fell into three categories:

(a) the group's own description of its experience and habits;

(b) the objective description of the group's experience as recorded by various authorities and agencies;

(c) the outsider's description of the group and its characteristics as seen by the external world. 
Main Objectives Related to Appraisal of Hypotheses and Techniques:

(1) To confirm the opinion that the combination of the three methods of obtaining data -household survey, analyses of all records, external information-was essential to secure a full picture of the group's experience, and that this combination could in practice be realized.

(2) To examine whether the aspects selected as relevant to the spread of disease in a small community could be usefully investigated by this combination of methods, and whether the findings could be collated.

(3) To give the research team experience both of the techniques in application, and of the answers to the questions, the data kept in records, and the judgements of outside informers.

Although this investigation was to be a preliminary to a long-term tuberculosis research project, it was considered necessary that it should in certain respects stand by itself as a socio-medical inquiry. Tuberculosis as a social disease was not expected to involve a different set of social factors from those of other social diseases. Specific objectives were therefore put forward in addition to the general assessment of techniques in application and of factors to be investigated:

I. To obtain sound basic data for the group-for example, population data, family and household structure, economic and occupational circumstances-which could be reliably used in other fields or in a follow-up of this investigation.

II. To investigate the type of bias and limitation attached to different methods of measuring sickness. Single-source data such as those of sample surveys, hospital-treated sickness, sickness benefit claims, and infectious-disease notifications, could be compared, and the discrepancies revealed between the single pictures could perhaps be measured.

It was hoped to maintain the relations to be established with this community in the future, to visit this community again, and to lay the basis of regular assessment of sickness and social experience at different seasons over a period of years.

\section{Methods}

The value of the methods and the reliability of the results depended on a carefully-taken random sample which represented the whole group. The size of the sample decided on was 10 per cent. of the total households in the area. A random sample was drawn, and where possible the sample was checked against the whole community as being representative of size of house, location of flat, type of household and so on.

The information wanted had to be defined and detailed, since it was to be obtained from three types of source:

(i) household interviewing and individual questioning,

(ii) investigations of all available records of persons or families in the sample,

(iii) statements made by outside persons who stand in some relation of authority, responsibility, or service to the group.

(1) Household ENQuiry.-The subjects of enquiry were limited to:

(a) House: occupancy and usage, washing and sleeping arrangements, etc.,

(b) Food: patterns of meals and feeding habits, cost and frequency of shopping, types of food bought and ready-cooked foods eaten, mid-day meal taken, food preferences, etc.,

(c) General Health: sickness experience, childhood ailments, use of patent medicines, experience of chronic ailments, illnesses in current month, duration and disability caused, major illnesses in previous 12 months,

(d) Leisure Habits: activities engaged in regularly or occasionally, weeknight and weekend habits, frequency of young people "going out" in evenings, travelling involved.

The household and individual questionnaires dealt with these four aspects of daily life. 
The questions themselves were of three kinds:
(i) matters of fact,
(ii) matters of opinion,
(iii) matters relating to attitudes and habits.

Special emphasis was placed on the household unit, and the schedule for the housewife included material for the whole household as well as questions about herself. She was asked about the house and its usage, about shopping and meal habits, about family history, and about the children's health. The adults were questioned about leisure habits, circumstances of travelling and of eating at work or elsewhere, and recent health experience.

(2) InVESTigations of Recorded Data.-Apart from the four topics $(a)-(d)$, economic status and social difficulties were also studied. Employment and occupational experiences were examined, and financial assistance to household earnings from national agencies or from pensions and benefits was noted. Sickness data were collected from the records of doctors, hospitals, schools, and public health authorities. Social disharmonies, such as minor absenteeism from school, frequent changes of jobs by juveniles, delinquency and petty offences, were investigated, and the social difficulties expressed through appeals to welfare organizations and guidance councils were noted.

(3) Opinions and Attitudes of Officials and Outside Observers.-These informants were approached for their knowledge and opinions of the main characteristics of the group, and were only prompted or questioned further if their statements needed clarification. Their opinions on aspects of group life other than those of particular interest in this enquiry were noted but not pursued.

All the data thus obtained were analysed to give separate tables and distributions of population, households, sickness, unemployment, assistance, social difficulties, offences, and the like. The material was collated and combined into a composite description of the group. In this paper the material presented is limited to that relating to the demographic aspects and sickness experience, since these are basic to the whole study. Other aspects concerning the socio-economic circumstances of the group and the more detailed data for particular categories such as children will be discussed in a subsequent paper.

\section{The Community Studied}

The community from which the sample was drawn comprises nearly 2,000 households living on a Local Authority housing estate built in the mid-1930s. The streets within the estate have no buildings other than the tenements with their four or six houses "on a stair". The main road running along the city side of the estate contains some shops, two primary schools, churches, a cinema, and some houses. The other three boundary roads are bus routes and consist almost entirely of houses; one has a few shops, and another the third primary school of the area. The nearest secondary school lies a short distance from the boundary. The nearest places of work are also beyond the boundary, but there are several very large concerns close by. There is no community centre on the estate and no provision for communal activities for adults or young people except for a boys' club hall. Transport to the city is freely available by two bus routes skirting the estate and by tram routes within walking distance. 
All the houses contain a living room whose open fire maintains the hot-water system, a small kitchenette with a gas cooker, a bathroom, a medium-sized bedroom, and one or two extremely small additional bedrooms. The common stair in these tenements gives access both to the street and to the common "back green".

The families which originally populated the estate nearly all came from an adjacent densely-crowded area, whose inhabitants are employed mainly in local concerns, and where there are numerous shops and many social facilities. The rehoused families were mainly large and growing ones, which were overcrowded in their existing houses (and rehoused on that account); and the parents were mainly young couples whose families were not yet complete.

Changes in the population have taken place as a few of the original families have moved from the estate. Their places were filled by other families placed on the housing waiting list because of overcrowding or some other priority. Other changes occurred as children grew up and married, or because of the war. Many of the men returned from the Services do not follow the same occupation as before the war, but on the whole people still work within reasonable distance of their homes, and in our sample nearly all the workers came home for midday dinner.

A great many of the families on the estate have become related by inter-marriage; in the sample, groups of five, six, or more families were inter-related by the marriages of several children. The bulk of the population consists of the remaining members of the original families, and a large proportion of these contain married daughters or sons with their young husbands or wives. The population is thus a comparatively stable one, and in many cases families move only from one part of the estate to another. In the sample of 198 households the length of residence of the parent families in their present house is shown in Table I.

TABLE I

Length of Residence of Parent Families in 10 Per Cent. SAmple, April, 1951

\begin{tabular}{l|c|c|c|c|c|c|c|c}
\hline Year of Moving In $\quad \cdots$ & $1935-38$ & $1939-40$ & $1941-42$ & $1943-44$ & $1945-46$ & $1947-48$ & $1949-51$ \\
\hline Duration of residence (years) & $14-17$ & $12-13$ & $10-11$ & $7-9$ & $5-6$ & $3-4$ & 2 or less \\
\hline Percentage of Main Households & 42 & 25 & 8 & 7 & 3 & $5 \frac{1}{2}$ & $7 \frac{1}{2}$ \\
\hline
\end{tabular}

Nearly half the sample families were among the earliest settlers, and another quarter moved in during the years in which the estate was being completed in the middle 1930s. Many of the original habits of this population are still retained. Much of the shopping is done in the neighbouring parent area, visits to relatives in the parent area are constant, and some of the inter-marriages are between relatives in the parent area and young people on the estate. Leisure activities also centre largely in the parent area or in the central city area.

The sample group was taken by a random selection of houses, and all persons in each sample household were studied. Of the 198 houses, 56 contained more than one family, most of them being related in-laws. Table II (opposite) shows that the 
TABLE II

Size of Households, April, 1951

\begin{tabular}{|c|c|c|c|c|c|c|c|c|c|c|c|c|c|}
\hline Number of Occupants & 1 & 2 & 3 & 4 & 5 & 6 & 7 & 8 & 9 & 10 & 11 & 12 & All \\
\hline Number of Households of & 2 & 20 & 25 & 46 & 38 & 24 & $2 i$ & 12 & 6 & 1 & 2 & 1 & 100 \\
\hline & \multicolumn{3}{|c|}{47} & \multicolumn{2}{|c|}{84} & \multicolumn{2}{|c|}{45} & \multicolumn{5}{|c|}{24} & \\
\hline \multirow{2}{*}{$\begin{array}{l}\text { Number of Persons included } \\
\text { in Households of this Size }\end{array}$} & \multirow{2}{*}{\multicolumn{3}{|c|}{$\underbrace{240}_{117}$}} & \multirow{2}{*}{\multicolumn{2}{|c|}{$\underbrace{184}_{374} 190$}} & \multirow{2}{*}{\multicolumn{2}{|c|}{$\underbrace{144 \quad 147}_{291}$}} & 96 & 54 & 10 & 22 & 12 & \multirow{2}{*}{976} \\
\hline & & & & & & & & \multicolumn{5}{|c|}{194} & \\
\hline
\end{tabular}

distribution of households by numbers of occupants centres in the household of four or five persons, but very many households contain six, seven, or more persons. Thus 50 per cent. of the sample population of 976 persons live six or more per house, and 20 per cent. live eight or more per house.

Table III shows the composition of this population, by age and sex; the distribution is bi-modal rising to one peak in the 15 to 19-year age group and to another for the 40 to 49 -year age group. The deficits among the 16 to 24 -year-old men are explicable, because we did not count young men who were members of the households but were away on national service and, therefore, absent when the survey was conducted. The deficit in the 35 to 44 -year-old men can be partly associated with the

TABLE III

Persons in 10 per cent. Sample (198 households), by Age and Sex, April, 1951

\begin{tabular}{|c|c|c|c|c|c|c|c|c|}
\hline \multirow{2}{*}{\multicolumn{3}{|c|}{ Age Group }} & \multicolumn{2}{|c|}{ Male } & \multicolumn{2}{|c|}{ Female } & \multicolumn{2}{|c|}{ Both Sexes } \\
\hline & & & No. & Per cent. & No. & Per cent. & No. & Per cent. \\
\hline $\begin{array}{r}0- \\
1-4 \\
5-9 \\
10-14 \\
15 \\
16-19\end{array}$ & $\begin{array}{l}\ldots \\
\cdots \\
\cdots \\
\cdots \\
.\end{array}$ & $\begin{array}{l}. \\
\cdots \\
\cdots \\
\ldots \\
.\end{array}$ & $\begin{array}{r}4 \\
44 \\
39 \\
64 \\
14 \\
44\end{array}$ & $\begin{array}{r}\cdot 8 \\
9 \cdot 2 \\
8 \cdot 2 \\
13 \cdot 4 \\
2 \cdot 9 \\
9 \cdot 2\end{array}$ & $\begin{array}{r}5 \\
29 \\
40 \\
65 \\
20 \\
59\end{array}$ & $\begin{array}{r}1 \cdot 0 \\
5 \cdot 8 \\
8 \cdot 0 \\
13 \cdot 0 \\
4 \cdot 0 \\
11 \cdot 8\end{array}$ & $\begin{array}{r}9 \\
73 \\
79 \\
129 \\
34 \\
103\end{array}$ & $\begin{array}{r}\cdot 9 \\
7 \cdot 5 \\
8 \cdot 1 \\
13 \cdot 2 \\
3 \cdot 5 \\
10 \cdot 6\end{array}$ \\
\hline $\begin{array}{l}20-24 \\
25-29 \\
30-34 \\
35-39 \\
40-44\end{array}$ & $\begin{array}{l}\ldots \\
\cdots \\
\cdots \\
\ldots\end{array}$ & $\begin{array}{l}\ldots \\
\cdots \\
\cdots \\
\cdots\end{array}$ & $\begin{array}{l}42 \\
43 \\
21 \\
18 \\
29\end{array}$ & $\begin{array}{l}8 \cdot 8 \\
9 \cdot 0 \\
4 \cdot 4 \\
3 \cdot 8 \\
6 \cdot 1\end{array}$ & $\begin{array}{l}46 \\
32 \\
20 \\
26 \\
42\end{array}$ & $\begin{array}{l}9 \cdot 2 \\
6 \cdot 4 \\
4 \cdot 0 \\
5 \cdot 2 \\
8 \cdot 4\end{array}$ & $\begin{array}{l}88 \\
75 \\
41 \\
44 \\
71\end{array}$ & $\begin{array}{l}9 \cdot 0 \\
7 \cdot 7 \\
4 \cdot 2 \\
4 \cdot 5 \\
7 \cdot 3\end{array}$ \\
\hline $\begin{array}{l}45-49 \\
50-54 \\
55-59 \\
60-64\end{array}$ & $\begin{array}{l}\ldots \\
\ldots \\
\ldots\end{array}$ & $\begin{array}{l}\ldots \\
\ldots \\
\ldots\end{array}$ & $\begin{array}{l}32 \\
30 \\
17 \\
14\end{array}$ & $\begin{array}{l}6 \cdot 7 \\
6 \cdot 3 \\
3 \cdot 6 \\
2 \cdot 9\end{array}$ & $\begin{array}{l}35 \\
27 \\
20 \\
20\end{array}$ & $\begin{array}{l}7 \cdot 0 \\
5 \cdot 4 \\
4 \cdot 0 \\
4 \cdot 0\end{array}$ & $\begin{array}{l}67 \\
57 \\
37 \\
34\end{array}$ & $\begin{array}{l}6 \cdot 9 \\
5 \cdot 8 \\
3 \cdot 8 \\
3 \cdot 5\end{array}$ \\
\hline $\begin{array}{l}65-69 \\
70-74 \\
75-79 \\
80\end{array}$ & $\begin{array}{l}\cdots \\
\cdots \\
\cdots\end{array}$ & $\begin{array}{l}. \\
\therefore \\
\therefore\end{array}$ & $\begin{array}{r}11 \\
9 \\
1 \\
-\end{array}$ & $\begin{array}{r}2 \cdot 3 \\
1.9 \\
\cdot 2 \\
-\end{array}$ & $\begin{array}{l}4 \\
8 \\
1 \\
1\end{array}$ & $\begin{array}{r}\cdot 8 \\
1.6 \\
\cdot 2 \\
\cdot 2\end{array}$ & $\begin{array}{r}15 \\
17 \\
2 \\
1\end{array}$ & $\begin{array}{r}1 \cdot 5 \\
1.7 \\
\cdot 2 \\
\cdot 1\end{array}$ \\
\hline Total & & .. & 476 & 100 & 500 & 100 & 976 & 100 \\
\hline
\end{tabular}


losses of the last war. The deficit in young children is not so easily explained until the family composition of the sample is examined.

Table IV shows the numbers of households containing, in addition to the main

TABLE IV

Particulars of 198 Households in 10 Per Cent. Sample, April, 1951

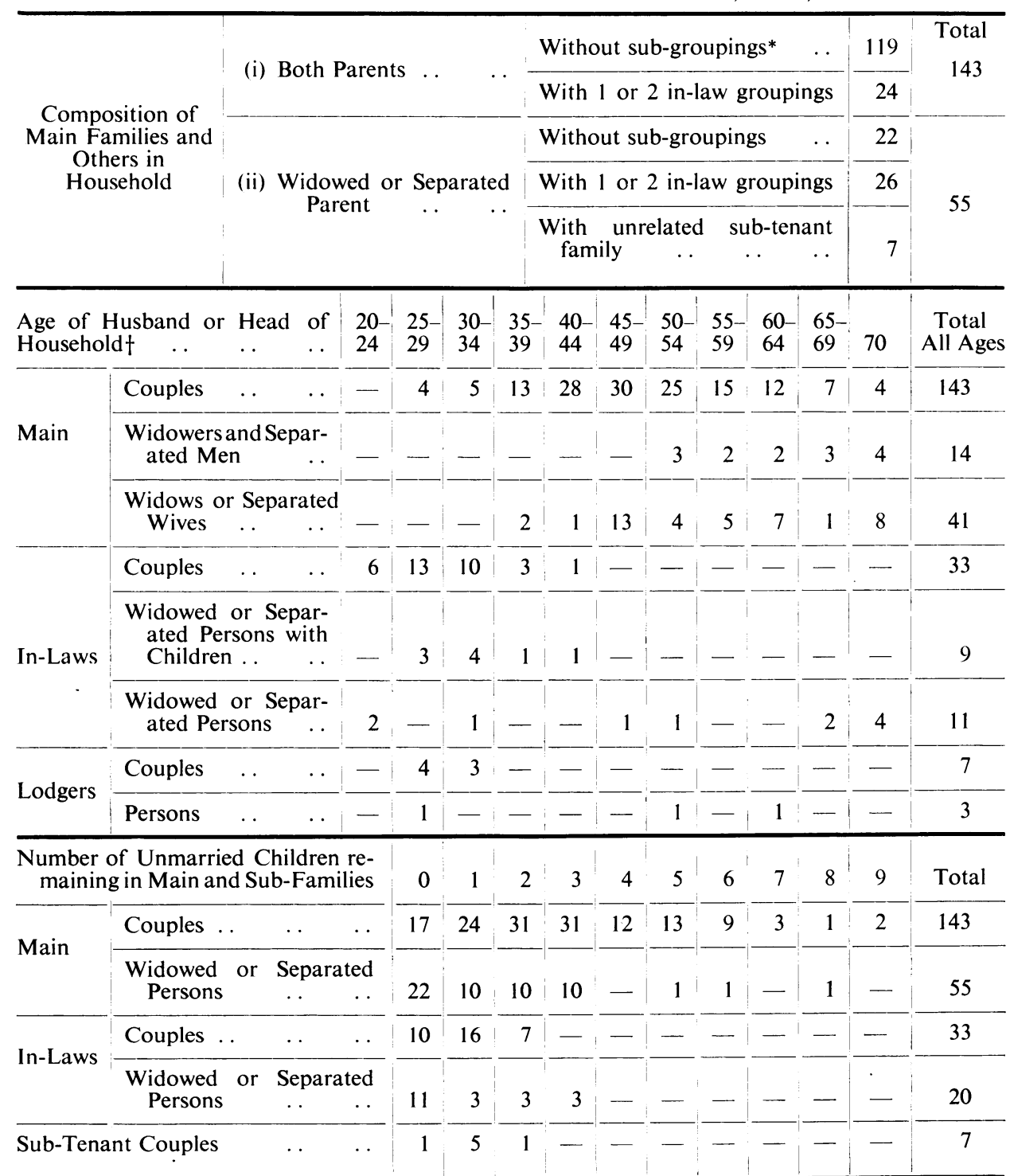

* Sub-groupings within the main households are defined as married couples or widowed or separated persons who occupy a room (with their children, if any), and have separate arrangements for meals and other domestic affairs.

$t$ The Head of the Household is taken to be the male tenant responsible for the house. In some households there is an older person (father-in-law or mother-in-law) who is not the head. In households in which there is no husband, the widow or the married separated wife is counted as the head of the household. 
family, one or more young families still living in the parent household. The ages of the parent couples or widowed householders are distributed about the 45 to 49 -year group, while those of the in-law couples centre in the 25 to 29-year group.

In addition to the 49 households in which a young married couple resides in the parent household, there are seven households containing two additional young families, most of them young couples awaiting a house of their own. These circumstances may explain the deficit of young children in the population of the sample. There are ten young couples with no children and 22 with only one.

TABLE V

Composition of 198 Households in 10 per Cent. Sample, April 1951

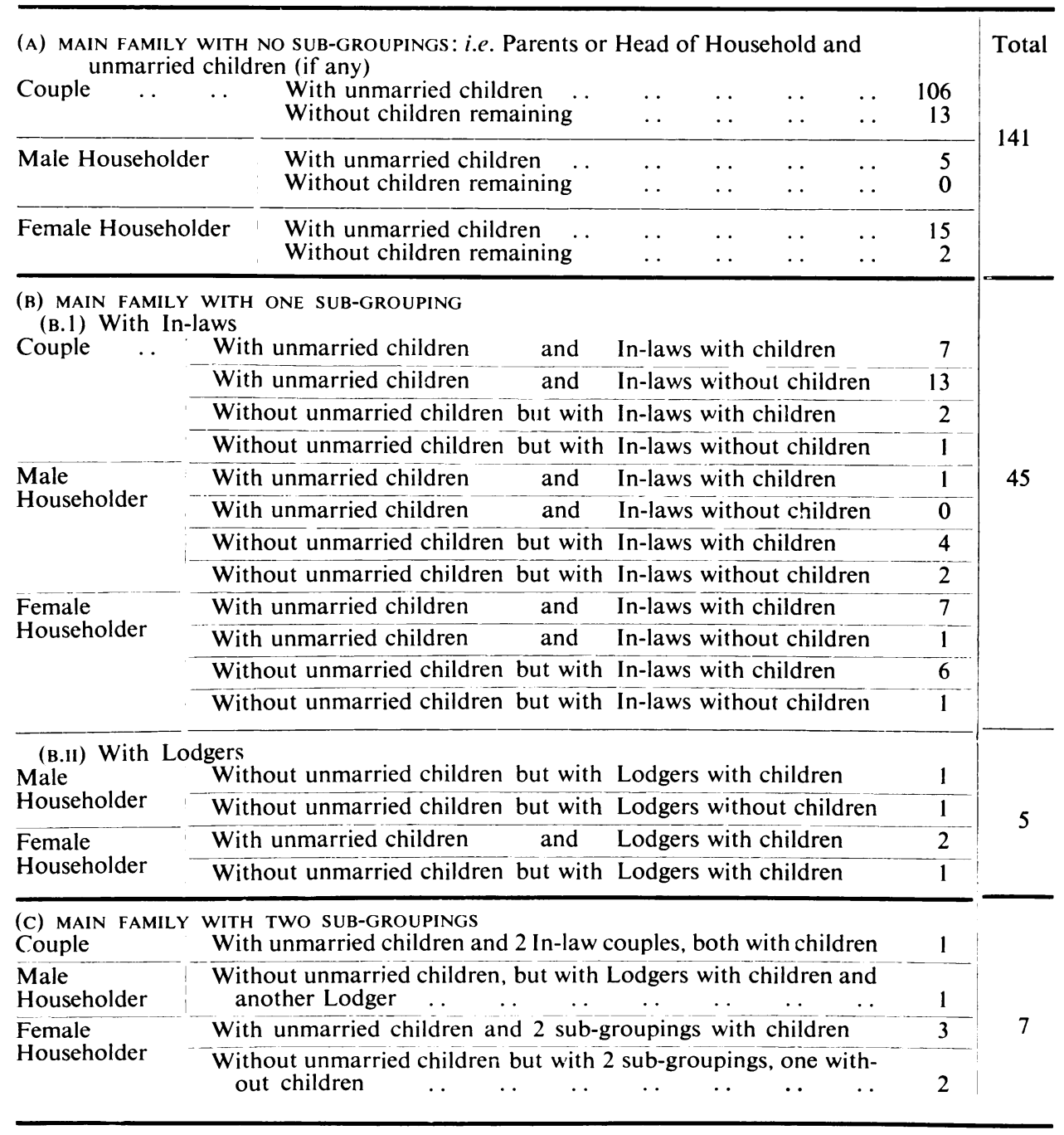


There are, however, a large number of "three-generation" households, comprising the main couple, a married son or daughter, and a grandchild or grandchildren. The composition of the 198 households is shown in Table $\mathrm{V}$ (previous page) which also includes the few families containing lodger couples or families. Sub-letting is not officially permitted, but in exceptional cases where an elderly person is left as sole occupant by the death of the spouse and the house is therefore too large, the authorities are not adamant about lodgers. The number of lodgers is extremely small, and in all except one case the families lived almost as if the lodgers were relations. The sharing of a kitchen, certain shopping and cooking arrangements, and some of the daytime activities were those of one household just as they were in those families where the young couple was closely related. The evening meal and other private arrangements were also similar for lodgers and for young in-laws.

It can be seen that the three-generation households constitute over one-sixth of all households in the sample; if the lodging families are included in three-generation households (as in fact their habits show that they should be) the proportion is one-fifth.

Thus this sample represents a population containing a large proportion of elderly

TABLE VI

Age, Sex, and Civil Status of Population in 10 per cent. Sample, April 1951

\begin{tabular}{|c|c|c|c|c|c|c|c|c|c|}
\hline \multirow{2}{*}{ Age Group } & \multicolumn{3}{|c|}{ Male } & \multicolumn{3}{|c|}{ Female } & \multicolumn{3}{|c|}{ Both Sexes } \\
\hline & Single & Married* & Widowed & Single & Married & * Widowed & Single & Married* & Widowed \\
\hline $0-9$ & 87 & . & .. & 74 & . & $\quad$. & 161 & . & $\ldots$ \\
\hline $10-14$ & 64 & . & . & 65 & . & $\ldots$ & 129 & . & . \\
\hline $\begin{array}{l}15-19 \\
20-24 \\
25-29 \\
30-34\end{array}$ & $\begin{array}{r}58 \\
37 \\
20 \\
4\end{array}$ & $\begin{array}{r}5 \\
23 \\
17\end{array}$ & $\begin{array}{l}\ldots \\
\cdots \\
\cdots \\
\cdots\end{array}$ & $\begin{array}{r}79 \\
30 \\
9 \\
4\end{array}$ & $\begin{array}{l}16 \\
23 \\
16\end{array}$ & $\begin{array}{l}. \\
\cdots \\
\cdots \\
\cdots\end{array}$ & $\begin{array}{r}137 \\
67 \\
29 \\
8\end{array}$ & $\begin{array}{l}21 \\
46 \\
33\end{array}$ & $\begin{array}{l}\ldots \\
\cdots \\
\cdots \\
.\end{array}$ \\
\hline $15-34$ & 119 & 45 & . & 122 & 55 & .. & 241 & 100 & .. \\
\hline $\begin{array}{l}35-39 \\
40-44 \\
45-49 \\
50-54\end{array}$ & $\begin{array}{l}2 \\
\mathrm{i} \\
2\end{array}$ & $\begin{array}{l}16 \\
29 \\
31 \\
25\end{array}$ & $\begin{array}{l}. \\
\cdots \\
\cdots\end{array}$ & $\begin{array}{l}1 \\
1 \\
\cdots \\
.\end{array}$ & $\begin{array}{l}24 \\
40 \\
25 \\
23\end{array}$ & $\begin{array}{r}1 \\
1 \\
10 \\
4\end{array}$ & $\begin{array}{l}3 \\
1 \\
1 \\
2\end{array}$ & $\begin{array}{l}40 \\
69 \\
56 \\
48\end{array}$ & $\begin{array}{r}1 \\
1 \\
10 \\
7\end{array}$ \\
\hline $35-54$ & 5 & 101 & 3 & 2 & 112 & 16 & 7 & 213 & 19 \\
\hline $\begin{array}{l}55-59 \\
60-64 \\
65-69 \\
70-74\end{array}$ & $\begin{array}{l}\ldots \\
\ldots \\
\ldots \\
\ldots\end{array}$ & $\begin{array}{r}15 \\
12 \\
8 \\
5\end{array}$ & $\begin{array}{c}2 \\
2 \\
3 \\
4\end{array}$ & $\begin{array}{l}\cdots \\
i \\
.\end{array}$ & $\begin{array}{r}15 \\
13 \\
2\end{array}$ & $\begin{array}{l}5 \\
7 \\
1 \\
8\end{array}$ & $\begin{array}{l}\cdots \\
i \\
.\end{array}$ & $\begin{array}{r}30 \\
25 \\
10 \\
5\end{array}$ & $\begin{array}{r}7 \\
9 \\
4 \\
4 \\
12\end{array}$ \\
\hline $55-74$ & . & 40 & 11 & 1 & 30 & 21 & 1 & 70 & 32 \\
\hline 75 & . & . & 1 & . & . & 2 & .. & $\ldots$ & 3 \\
\hline Totals & 275 & 186 & 15 & 264 & 197 & $\begin{array}{l}39 \\
\square\end{array}$ & 539 & 383 & 54 \\
\hline
\end{tabular}

* "Married" includes those living apart from the spouse. 
couples, whose older children have married and moved away, whilst their younger children, married or unmarried, are still living with them, and a few grandchildren are growing up in the families. The population pyramid illustrates clearly the ages in which the sample lacks the normal complement of young adults. This is equally illustrated by the age-sex-civil state composition detailed in Table VI (previous page). The numbers of single or married are sharply differentiated by age; there are only seven single women and nine single men over the age of 30 .

On the other hand, sixteen of the 39 widowed women are under the age of 55 , and most of these have children to support. The 197 married women include thirteen living apart from their husbands. Only a very few of these separated wives are young women with no children; the majority have several children, and one has eight still with her and others grown up and gone away. The majority of these separated wives are main householders with all the associated responsibilities; only a few of them live with their children in the parent household. The cases of the two separated husbands with young children are not due to marital difficulties but to long-term hospitalization of the wives.

The composition of the child population, shown in Table VII, is of some interest. Even in this sample the uneven numbers of births in the last 15 years and the sharp decreases and increases during the war and immediate post-war years are evident.

The general decline in births is probably as strongly associated with the household and family composition as with the declining birthrate in the whole country. The average annual birthrate in the sample during the past 18 months is $13 \cdot 3$, the most recent city birthrate being $15 \cdot 7$ per 1,000 estimated population.

TABLE VII

Young Persons in Households of 10 per Cent. Sample by Sex and Age, April 1951

\begin{tabular}{|c|c|c|c|c|c|c|c|}
\hline \multicolumn{2}{|c|}{ Age in Years } & \multicolumn{2}{|c|}{ Male } & \multicolumn{2}{|c|}{ Female } & \multicolumn{2}{|c|}{ Both Sexes } \\
\hline $0-4$ & $\begin{array}{l}0 \\
1 \\
2 \\
3 \\
4\end{array}$ & $\begin{array}{r}4 \\
9 \\
8 \\
10 \\
17\end{array}$ & 48 & $\begin{array}{r}5 \\
6 \\
5 \\
7 \\
11\end{array}$ & 34 & $\begin{array}{r}9 \\
15 \\
13 \\
17 \\
28\end{array}$ & 82 \\
\hline $5-9$ & $\begin{array}{l}5 \\
6 \\
7 \\
8 \\
9\end{array}$ & $\begin{array}{r}7 \\
6 \\
13 \\
9 \\
4\end{array}$ & 39 & $\begin{array}{r}7 \\
5 \\
9 \\
10 \\
9\end{array}$ & 40 & $\begin{array}{l}14 \\
11 \\
22 \\
19 \\
13\end{array}$ & 79 \\
\hline $10-14$ & $\begin{array}{l}10 \\
11 \\
12 \\
13 \\
14\end{array}$ & $\begin{array}{r}8 \\
8 \\
19 \\
11 \\
18\end{array}$ & 64 & $\begin{array}{r}17 \\
7 \\
15 \\
13 \\
13\end{array}$ & 65 & $\begin{array}{l}25 \\
15 \\
34 \\
24 \\
31\end{array}$ & 129 \\
\hline $15-19$ & $\begin{array}{l}15 \\
16 \\
17 \\
18 \\
19\end{array}$ & $\begin{array}{c}14 \\
18 \\
12 \\
11 \\
3^{*}\end{array}$ & 58 & $\begin{array}{r}20 \\
17 \\
11 \\
8 \\
23\end{array}$ & 79 & $\begin{array}{l}34 \\
35 \\
23 \\
19 \\
26\end{array}$ & 137 \\
\hline Total & & & 209 & & 218 & & 427 \\
\hline
\end{tabular}
sample. 
The uneven numbers of births in years when external social or political events sharply affected family life indicate other problems superimposed upon that of a declining birthrate. The provision of services and facilities for children is difficult when numbers fluctuate so much.

Many other social characteristics of the sample are linked to a greater or lesser degree with the demographic structure of the population in the area. The problems of children growing up in three-generation households are intensified where the young mother is separated from her husband; for separated women who are main householders, the difficulties of running a home, earning a living, and caring for the children are even greater.

For the community as a whole, the present composition of the population has more serious results. It has been shown that the present structure comes from two distributions of different age-spread superimposed upon one another: the majority of the population is that of the original families whose members have grown old, while the smaller distribution at the younger ages is that of the children who have married and settled with their partners in the parent house. Such a population, with its deficits of persons in their thirties and its excess of older couples, would have problems even with no housing shortage. In addition, the housing shortage may well be associated with the restriction of the family size of the young couples awaiting a house of their own, and may lead to an even more unbalanced population structure. These two distributions of persons in the population typify the two major problems of such a re-housed community-the many elderly couples, and the overcrowding which ensues as the family expands in houses which do not expand.

The importance of a population composition of this kind extends far beyond this estate: it seems inevitable that the building of housing estates and the policy of populating them with families whose present needs are great will result in similar populations of similar composition as time goes on. As the population on an estate ages still more, other wide-spread problems must arise. Meanwhile, the limitation of family size and the continuous overcrowding of parent households seems likely to continue while the serious housing shortage continues.

\section{Health and Sickness in the Community}

Within the estate, the usual local and national health and social agencies operate, and services of many kinds are available. The different Health Visitors concern themselves with the welfare of infants, school children, and certain sick people, and there is a Child Welfare Clinic in the centre of the estate. Two District Nurses live on the edge of the estate, and various social welfare organizations have workers in close touch with the community.

A number of doctors are in contact with the estate, but most of the families are within the practices of one group of doctors who have served this community since its inception. Over 80 per cent. of the population in the sample were found to be their patients; the composition of this portion of the sample is shown in Table VIII. Table VIII (and Fig. 1, overleaf) show that this "practice population" is composed 
TABLE VIII

Sample Population in Practices of Main Doctors, by Age and Sex, April, 1951

\begin{tabular}{|c|c|c|c|c|c|c|c|c|}
\hline \multirow{2}{*}{\multicolumn{3}{|c|}{ Age Group }} & \multicolumn{2}{|c|}{ Male } & \multicolumn{2}{|c|}{ Female } & \multicolumn{2}{|c|}{ Both Sexes } \\
\hline & & & No. & Per cent. & No. & Per cent. & No. & Per cent. \\
\hline $\begin{array}{r}0- \\
1-4 \\
5-9 \\
10-14 \\
15 \\
16-19\end{array}$ & $\begin{array}{l}. \\
. \\
. \\
. \\
.\end{array}$ & $\begin{array}{l}. \\
. \\
. \\
. \\
.\end{array}$ & $\begin{array}{r}2 \\
42 \\
31 \\
56 \\
11 \\
34\end{array}$ & $\begin{array}{r}\cdot 5 \\
10 \cdot 6 \\
7 \cdot 8 \\
14 \cdot 1 \\
2 \cdot 8 \\
8 \cdot 6\end{array}$ & $\begin{array}{r}5 \\
24 \\
32 \\
54 \\
17 \\
49\end{array}$ & $\begin{array}{r}1 \cdot 2 \\
5 \cdot 8 \\
7 \cdot 8 \\
13 \cdot 1 \\
4 \cdot 1 \\
11 \cdot 9\end{array}$ & $\begin{array}{r}7 \\
66 \\
63 \\
110 \\
28 \\
83\end{array}$ & $\begin{array}{r}.9 \\
8 \cdot 2 \\
7 \cdot 8 \\
13 \cdot 6 \\
3 \cdot 5 \\
10 \cdot 3\end{array}$ \\
\hline $\begin{array}{l}20-24 \\
25-29 \\
30-34 \\
35-39 \\
40-44\end{array}$ & $\begin{array}{l}. \\
\therefore \\
\therefore \\
.\end{array}$ & $\begin{array}{l}. \\
\therefore \\
\therefore \\
.\end{array}$ & $\begin{array}{l}38 \\
35 \\
21 \\
15 \\
22\end{array}$ & $\begin{array}{l}9 \cdot 6 \\
8 \cdot 8 \\
5 \cdot 3 \\
3 \cdot 8 \\
5 \cdot 6\end{array}$ & $\begin{array}{l}43 \\
27 \\
17 \\
18 \\
37\end{array}$ & $\begin{array}{r}10 \cdot 4 \\
6 \cdot 6 \\
4 \cdot 1 \\
4 \cdot 4 \\
9 \cdot 0\end{array}$ & $\begin{array}{l}81 \\
62 \\
38 \\
33 \\
59\end{array}$ & $\begin{array}{r}10 \cdot 0 \\
7 \cdot 7 \\
4 \cdot 7 \\
4 \cdot 1 \\
7 \cdot 3\end{array}$ \\
\hline $\begin{array}{l}45-49 \\
50-54 \\
55-59 \\
60-64\end{array}$ & $\begin{array}{l}. \\
. \\
.\end{array}$ & $\begin{array}{l}. \\
\therefore \\
\therefore \\
.\end{array}$ & $\begin{array}{r}25 \\
26 \\
15 \\
8\end{array}$ & $\begin{array}{l}6 \cdot 3 \\
6 \cdot 6 \\
3 \cdot 8 \\
2 \cdot 0\end{array}$ & $\begin{array}{l}29 \\
20 \\
16 \\
16\end{array}$ & $\begin{array}{l}7 \cdot 0 \\
4 \cdot 9 \\
3 \cdot 9 \\
3 \cdot 9\end{array}$ & $\begin{array}{l}54 \\
46 \\
31 \\
24\end{array}$ & $\begin{array}{l}6 \cdot 7 \\
5 \cdot 7 \\
3 \cdot 8 \\
3 \cdot 0\end{array}$ \\
\hline $\begin{array}{l}65-69 \\
70-74 \\
75-79 \\
80+\end{array}$ & $\begin{array}{l}. \\
\therefore \\
.\end{array}$ & $\begin{array}{l}. \\
. \\
. \\
.\end{array}$ & $\begin{array}{r}9 \\
5 \\
1 \\
-\end{array}$ & $\begin{array}{l}2 \cdot 3 \\
1 \cdot 3 \\
0 \cdot 3 \\
-\end{array}$ & $\begin{array}{l}2 \\
4 \\
1 \\
1\end{array}$ & $\begin{array}{l}0 \cdot 5 \\
1 \cdot 0 \\
0 \cdot 2 \\
0 \cdot 2\end{array}$ & $\begin{array}{r}11 \\
9 \\
2 \\
1\end{array}$ & $\begin{array}{l}1 \cdot 4 \\
1 \cdot 1 \\
0 \cdot 2 \\
0 \cdot 1\end{array}$ \\
\hline Total & .. & .. & 396 & 100 & 412 & 100 & 808 & 100 \\
\hline
\end{tabular}

of people of all ages whose distribution is almost identical with that of the full sample.

The sickness data assembled in this study were obtained from the different sources outlined above, from the doctors, and from interviews and questions in all the houses in the sample. The information from national and local authorities was abstracted in different ways according to the form and content of the records. Much of the basic background was provided by health agencies: but other agencies, whose main concern was with economic or social assistance, also provided much information on special aspects of sickness or disability recognized as contributing to the family need. But since each agency records only certain information relevant to that aspect of sickness for which it has to make provision, the picture obtained from records of outside agencies is not at all uniform. Thus, infectious diseases notifications to the Public Health Department are limited mainly to those of children's notifiable diseases, and these again mainly refer to the first case in the household if the child be under 5 years of age. Hospital records are concerned only with those persons brought to their notice, so that for example an older child brought to hospital because of an infectious disease will appear in hospital records. But infectious diseases of older children treated at home do not appear in any records save perhaps those of doctors. Similarly, other records include only a selected portion of the population actually sick: and the basis for selection is not necessarily a medical one. Claims for sickness benefit, for instance, do not include any sickness lasting less than three days. It appears that official records inevitably classify an illness as "new" at 
the stage when it is first brought to official notice. So each set of records describes not illness as it occurs but illness by the definition of what is conspicuous and is brought to the notice of the particular agency.

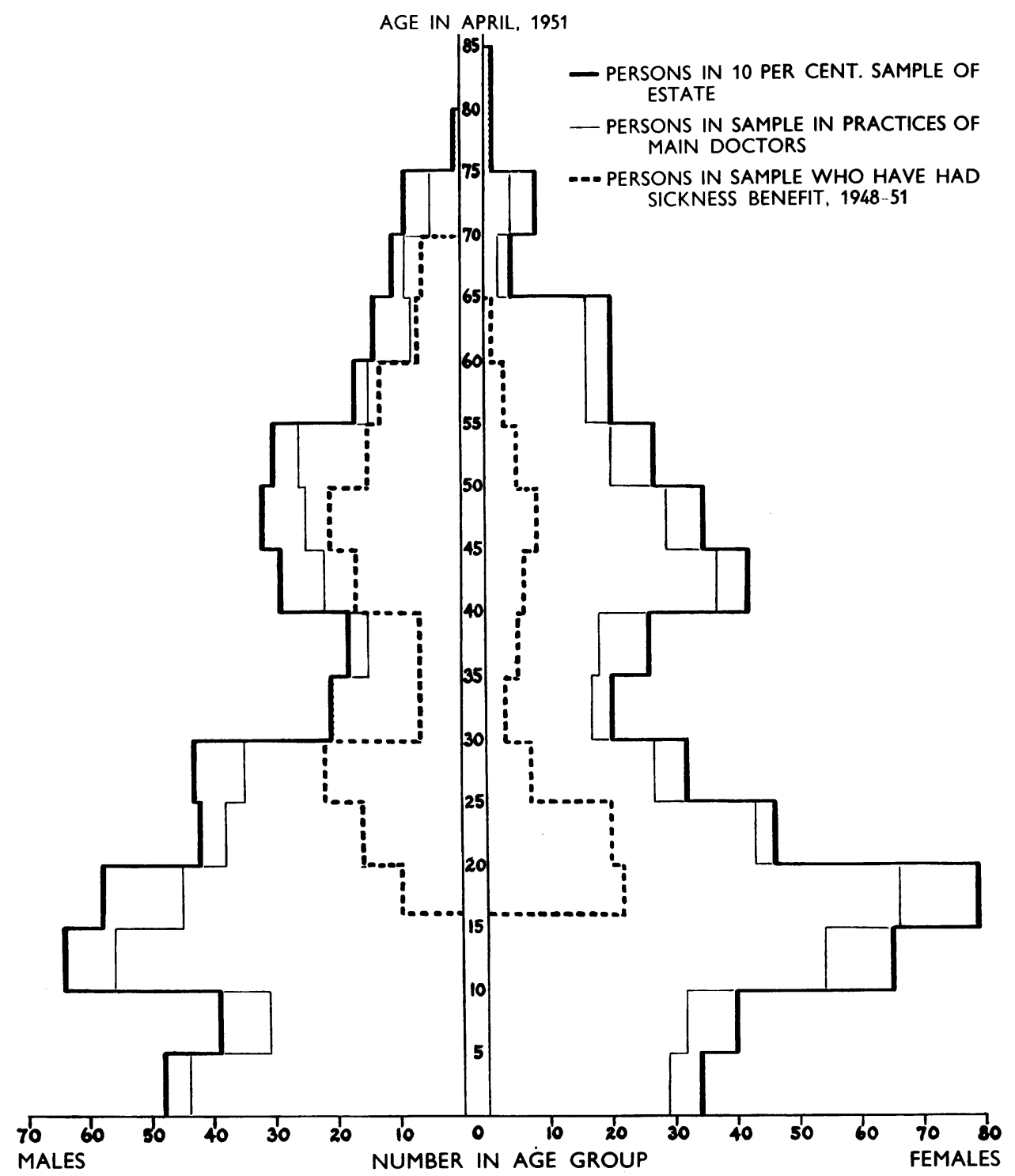

Fig. 1.-Persons attended by main doctors and drawing sick benefit, 1948-51. 
The sample survey questionnaire, investigating aspects of sickness additional to those concerning the official agencies, included one group of questions on sickness felt, disability caused, and common or recurrent ailments, and another on children's health, opinions of family health, habits relating to the maintenance of health, and the buying of patent medicines. The questions on family matters were addressed to the housewife, and individuals were asked about their own sickness experience.

A body of valuable material not usually obtainable was made available through the interest and co-operation of the main doctors in practice in the area. Through their records, details of the hospital-referrals and of some other recorded sickness in the "practice population" were obtained, and the doctors also made a detailed statement of all the common, recurrent, and chronic illnesses or complaints in all the households known to them through frequent contact. These full data, together with all the data from other sources, have provided an exceptionally comprehensive description of sickness from several viewpoints. Since the "practice population" forms such a very large proportion of the sample and represents its distribution so closely, this manysided description is considered to be indicative of the sickness in the whole community.

It is evident that each set of data, if taken alone, would present a very different picture not only of sickness in the community but also of the prevalence of specific diseases. However, most of the sets of data have a certain "overlap" which contains persons who come to more than one agency for some kind of aid. From this overlap it became apparent that different records were labelling different ștages of disease or even different aspects of sickness by the same name. Some system of uniform terminology was essential, and from our standpoint this could only begin with the persons who first suffered ill-health; this initial stage in ill-health was to be discovered by the survey questionnaire. The next stage in ill-health was that in which the patient consulted the doctor for advice and treatment. A further stage, in which diagnosis was obscure or illness serious, led to hospital referral; later stages were hospitalization, and, possibly, follow-up. At a variable point in this sequence, claims for benefit would be made by insured persons unable to continue working.

In collating the different records to build up this sequential picture of ill-health in the community, the various limited aspects of sickness, taken as discrete by separate agencies because their medical or social involvement was strictly limited, had to be carefully studied and defined. The "area of overlap" made it possible to arrive at some comparable standards for the different records, to combine them, and to obtain a composite record of "sickness officially recognized". The recognition of such sickness is based on criteria relating to available provision for the relief of urgent need-which may be financial or social. This is not similar to sickness recognized by the doctor, whose criterion is in the main that of conspicuous suffering, either traceable to an external cause or subjectively felt. It also differs from that recognized by the family of the sick person, for the family criteria are mainly non-medical: conspicuousness of unusual disability, disturbance to domestic routine, sympathetic attitude hoped for from the doctor, and difficulties involved at work or school in claiming disability. 
The most serious stage of illness is to be expected in the hospital-treated population. In the "practice population" households, the persons referred from 1948 onwards to hospital or public health services for observation and possible treatment constituted exactly 25 per cent. Table IX shows the age and sex distribution of this group and compares other records for the same "practice population"; and Fig. 2 illustrates these distributions. It can be seen that the numbers of hospital-referred men and women are very similar (23.7 and 26.2 per cent. respectively). In each age group there is little difference visible between males and females, but at the ages 10-14 and 15-19 the referrals seem to be high. In the older age groups the hospital referrals form a considerable proportion of the population at risk. Though the numbers are too small to admit of statistical interpretation, the greater hospital provision likely to be needed by an ageing population is clearly indicated.

TABLE IX

Recorded Sickness among "Practice Population" 1948-51, by Sex and Age Population in Practice (P) Additional Doctors' Records (D) Hospital Referrals (H) Claims for Sickness Benefit (C)

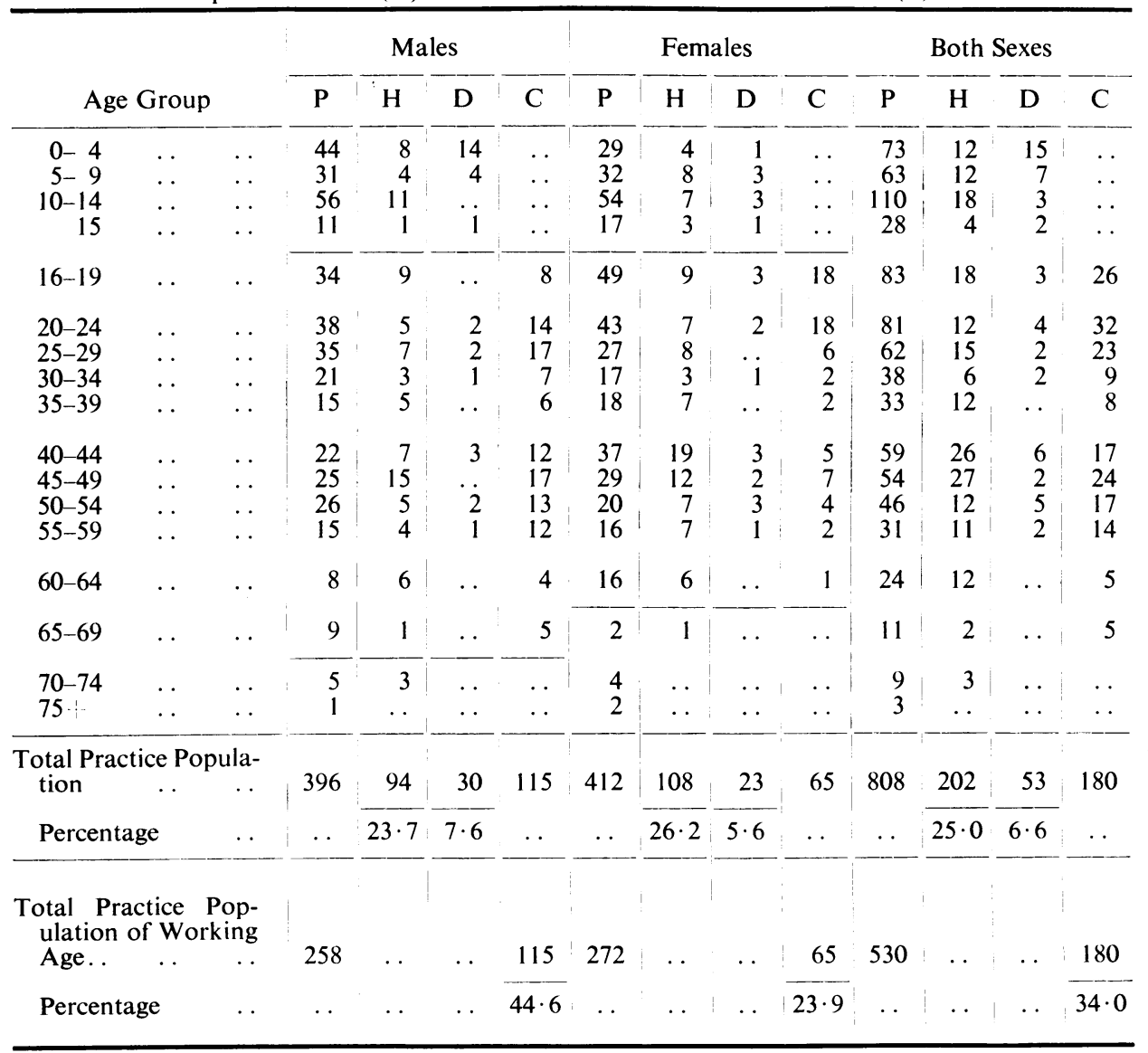




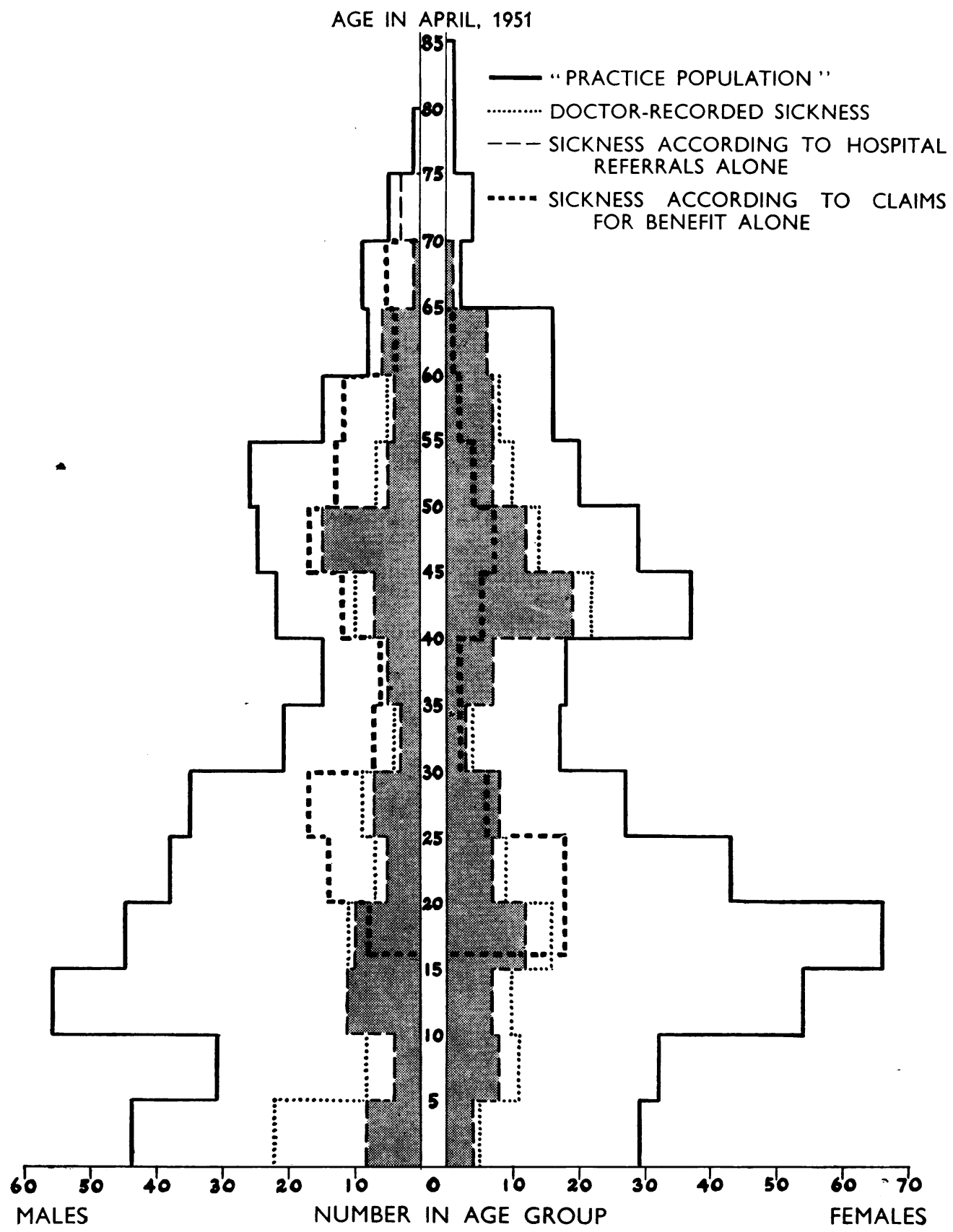

Fig. 2,-Persons with one or more recorded ailment, 1948-51. 
The doctors' records noted not only hospital referrals but also certain cases of illness, such as some infectious diseases, certificates in certain cases of incapacity, and complaints which might involve referral to another agency at some time in the future. Although these cannot by any means be taken as representing the full complement of such ailments in the community-since a doctor's recording depends on the time available and the place in which the patient is seen, as well as on the seriousness of the complaint - the children's infectious diseases recorded can be taken as representative. The recorded incidence of infectious diseases in small boys of pre-school age is significantly higher than that in girls of the same age. Whether this difference -which appears quite startling in the outline illustrating doctor-recorded sickness in Fig. 2-represents a real sex difference of such magnitude is debatable: it is certain that in this district mothers bring little boys more readily to the doctor.

The hospital-referred and doctor-recorded persons were found to suffer from a variety of ailments which are described in broad groups in Table X. The symptoms and diagnoses found in doctors' records, in sickness benefit claims, and in the answers to the survey questionnaire could not all be classified within a single diagnostic system. The classifications adopted are non-clinical, but as far as possible the groups preserve some clinical homogenity. The choice of these non-overlapping categories of sickness is necessarily arbitrary, and certain groups or diseases of particular interest have been picked out from larger groups. Many of the persons attending hospitals were found to be "multiple admissions" to the hospital system of the city,

TABLE $X$

Sickness among Population in Practices of Main Doctors, 1948-51

Hospital Referrals (H) Additional Doctors' Records'(D) Claims for Sickness Benefit (C)

\begin{tabular}{|c|c|c|c|c|c|c|c|c|c|c|c|c|c|}
\hline \multirow{2}{*}{\multicolumn{2}{|c|}{ Disease Group* }} & & & Male & & \multicolumn{4}{|c|}{ Female } & \multicolumn{4}{|c|}{ Both Sexes } \\
\hline & & $\begin{array}{c}\text { H } \\
\text { and } \\
D\end{array}$ & $\mathrm{C}$ & $\begin{array}{l}\mathrm{H} \\
\text { and } \\
\mathrm{D} \\
+\mathrm{C}\end{array}$ & $\begin{array}{l}\text { Per } \\
\text { cent. }\end{array}$ & $\begin{array}{c}\text { H } \\
\text { and } \\
D\end{array}$ & $\mathbf{C}$ & $\begin{array}{c}\text { H } \\
\text { and } \\
\mathrm{D} \\
+\mathrm{C}\end{array}$ & $\begin{array}{r}\text { Per } \\
\text { cent. }\end{array}$ & $\begin{array}{c}\text { H } \\
\text { and } \\
D\end{array}$ & $\mathrm{C}$ & $\begin{array}{l}\mathrm{H} \\
\text { and } \\
\mathrm{D} \\
+\mathrm{C}\end{array}$ & $\begin{array}{l}\text { Per } \\
\text { cent. }\end{array}$ \\
\hline $\begin{array}{l}\text { Respiratory } \\
\text { Ear, Nose, and } \mathrm{Tl}\end{array}$ & aroat & $\begin{array}{l}22 \\
17\end{array}$ & $\begin{array}{l}46 \\
11\end{array}$ & $\begin{array}{l}61 \\
27\end{array}$ & $\begin{array}{r}15 \cdot 4 \\
6 \cdot 8\end{array}$ & $\begin{array}{l}17 \\
19\end{array}$ & $\begin{array}{r}23 \\
7\end{array}$ & $\begin{array}{l}40 \\
26\end{array}$ & $\begin{array}{l}9 \cdot 7 \\
6 \cdot 3\end{array}$ & $\begin{array}{l}39 \\
36\end{array}$ & $\begin{array}{l}69 \\
18\end{array}$ & $\begin{array}{r}101 \\
53\end{array}$ & $\begin{array}{r}12 \cdot 5 \\
6 \cdot 6\end{array}$ \\
\hline $\begin{array}{ll}\text { Digestive } & \ldots \\
\text { Ulcer } \ldots & \ldots\end{array}$ & $\begin{array}{l}\cdots \\
\cdots\end{array}$ & $\begin{array}{l}16 \\
11\end{array}$ & $\begin{array}{l}9 \\
8\end{array}$ & $\begin{array}{l}23 \\
14\end{array}$ & $\begin{array}{l}5 \cdot 8 \\
3 \cdot 5\end{array}$ & $\begin{array}{r}13 \\
3\end{array}$ & $\begin{array}{l}4 \\
2\end{array}$ & $\begin{array}{r}16 \\
4\end{array}$ & $\begin{array}{l}3 \cdot 9 \\
1 \cdot 0\end{array}$ & $\begin{array}{l}29 \\
14\end{array}$ & $\begin{array}{l}13 \\
10\end{array}$ & $\begin{array}{l}39 \\
18\end{array}$ & $\begin{array}{l}4 \cdot 8 \\
2 \cdot 2\end{array}$ \\
\hline $\begin{array}{l}\text { Skin } \ldots \\
\text { Aches and Pains } \\
\text { Injuries } \\
\text { Gynaecological }\end{array}$ & $\begin{array}{l}\cdots \\
\cdots \\
\cdots \\
\cdots\end{array}$ & $\begin{array}{r}13 \\
5 \\
20 \\
\cdots\end{array}$ & $\begin{array}{r}8 \\
24 \\
37 \\
\cdots\end{array}$ & $\begin{array}{l}19 \\
28 \\
49 \\
\ldots\end{array}$ & $\begin{array}{l}4 \cdot 8 \\
7 \cdot 1 \\
12 \cdot 4 \\
\ldots\end{array}$ & $\begin{array}{l}16 \\
13 \\
12 \\
25\end{array}$ & $\begin{array}{l}2 \\
7 \\
9 \\
7\end{array}$ & $\begin{array}{l}18 \\
19 \\
16 \\
27\end{array}$ & $\begin{array}{l}4 \cdot 4 \\
4 \cdot 6 \\
3 \cdot 9 \\
6 \cdot 6\end{array}$ & $\begin{array}{l}29 \\
18 \\
32 \\
\cdots\end{array}$ & $\begin{array}{l}10 \\
31 \\
46 \\
\cdots\end{array}$ & $\begin{array}{l}37 \\
47 \\
65 \\
\cdots\end{array}$ & $\begin{array}{l}4 \cdot 6 \\
5 \cdot 8 \\
8 \cdot 0 \\
\ldots\end{array}$ \\
\hline $\begin{array}{l}\text { Measles .. } \\
\text { Whooping-cough } \\
\text { Scarlet Fever ... }\end{array}$ & $\begin{array}{l}\cdots \\
\cdots \\
\cdots\end{array}$ & $\begin{array}{r}13 \\
6 \\
1 \\
\end{array}$ & $\begin{array}{l}\cdots \\
\cdots \\
\cdots\end{array}$ & $\begin{array}{r}13 \\
6 \\
1\end{array}$ & $\begin{array}{l}3 \cdot 3 \\
1 \cdot 5 \\
\ldots\end{array}$ & $\begin{array}{l}3 \\
\cdots \\
\cdots\end{array}$ & $\begin{array}{l}\cdots \\
\cdots \\
\cdots\end{array}$ & $\begin{array}{l}3 \\
\cdots \\
\cdots\end{array}$ & $\begin{array}{l}\cdots \\
\cdots \\
\cdots\end{array}$ & $\begin{array}{r}16 \\
6 \\
1 \\
\end{array}$ & $\begin{array}{l}\cdots \\
\cdots \\
\cdots\end{array}$ & $\begin{array}{r}16 \\
6 \\
1\end{array}$ & $\begin{array}{l}2 \cdot 0 \\
\cdots \\
\ldots\end{array}$ \\
\hline & $\begin{array}{l} \\
\text { Respi } \\
\text { Ear, } \\
\text { Skin } \\
\text { Diges } \\
\text { Ulcer } \\
\text { Aches } \\
\text { Injuri } \\
\text { Gỵna }\end{array}$ & $\begin{array}{l}\text { Group } \\
\text { tory } \\
\text { ose, an } \\
\text { ve } \\
\text { and } \mathrm{Pa} \\
\text { cologic }\end{array}$ & $\begin{array}{l}\text { d Thr } \\
\therefore \\
\therefore \\
\text { ins } \\
\therefore\end{array}$ & $\begin{array}{cc}\ldots & \mathbf{C o} \\
\text { oat } & \text { To } \\
. & \mathbf{D e} \\
. . & \mathbf{G a} \\
\ldots & \mathbf{G a} \\
\ldots & \mathbf{R h} \\
. & \mathbf{B u} \\
. . & \mathbf{B r}\end{array}$ & $\begin{array}{l}\text { illitis, } \\
\text { natitis, } \\
\text { ric infe } \\
\text { ric, duo } \\
\text { umatism } \\
\text { s, conc } \\
\text { st absce }\end{array}$ & $\begin{array}{l}\text { flamm } \\
\text { oils, a } \\
\text { tions, } \\
\text { denal. } \\
\text { arthri } \\
\text { ssions. } \\
\text { is, mas }\end{array}$ & $\begin{array}{l}\text { Som } \\
\text { bu } \\
\text { tion } \\
\text { sces } \\
\text { ut } n \\
\text { is, } 1\end{array}$ & $\begin{array}{l}\text { the di } \\
\text { t pne } \\
\text { ear. } \\
\text { ulcers. } \\
\text { bago, }\end{array}$ & $\begin{array}{l}\text { rders in } \\
\text { nonia nc } \\
\text { iatica, } h\end{array}$ & uded & ator & uberc & \\
\hline
\end{tabular}


though not necessarily to any one hospital. Moreover, from the number of hospital attendances for specific diseases or groups of diseases, the calculated prevalence of certain ailments would appear much higher than the actual prevalence of the diseases assessed according to the number of persons suffering from them.

A further analysis of the material presented in Tables IX and X shows that young women are referred to a health agency for a multiplicity of reasons, among which the investigation of respiratory conditions is prominent. Among older men, respiratory disorders requiring hospital action are considerable. In all age groups above 25 , the additional doctor-records are few, and there is little sex difference either in numbers or in diseases recorded.

Claims for sickness benefit represent other criteria of seriousness of an illness, not necessarily through the involvement of a health agency, but through the incapacity

TABLE XI

Persons claiming Benefit and Number of Claims in full (10 per cent. Sample), 1948-51

\begin{tabular}{|c|c|c|c|c|c|c|c|}
\hline \multirow{2}{*}{\multicolumn{2}{|c|}{ Age Group }} & \multicolumn{2}{|c|}{ Male } & \multicolumn{2}{|c|}{ Female } & \multicolumn{2}{|c|}{ Both Sexes } \\
\hline & & $\begin{array}{c}\text { Number } \\
\text { of } \\
\text { Persons }\end{array}$ & $\begin{array}{l}\text { Claims } \\
\text { per } \\
\text { Person }\end{array}$ & $\begin{array}{l}\text { Number } \\
\text { of } \\
\text { Persons }\end{array}$ & $\begin{array}{l}\text { Claims } \\
\text { per } \\
\text { Person }\end{array}$ & $\begin{array}{c}\text { Number } \\
\text { of } \\
\text { Persons }\end{array}$ & $\begin{array}{l}\text { Claims } \\
\text { per } \\
\text { Person }\end{array}$ \\
\hline $16-19$ & $\left\{\begin{array}{l}\text { Claims } \\
\text { Persons }\end{array}\right.$ & $\begin{array}{l}19 \\
10\end{array}$ & $1 \cdot 9$ & $\begin{array}{l}31 \\
22\end{array}$ & $1 \cdot 41$ & $\begin{array}{l}50 \\
32\end{array}$ & $1 \cdot 56$ \\
\hline $20-24$ & $\left\{\begin{array}{l}\text { Claims } \\
\text { Persons }\end{array}\right.$ & $\begin{array}{l}27 \\
16\end{array}$ & $1 \cdot 69$ & $\begin{array}{l}31 \\
20\end{array}$ & $1 \cdot 55$ & $\begin{array}{l}58 \\
36\end{array}$ & $1 \cdot 61$ \\
\hline $25-29$ & $\left\{\begin{array}{l}\text { Claims } \\
\text { Persons }\end{array}\right.$ & $\begin{array}{l}32 \\
22\end{array}$ & $1 \cdot 45$ & $\begin{array}{r}16 \\
7\end{array}$ & $2 \cdot 29$ & $\begin{array}{l}48 \\
29\end{array}$ & $1 \cdot 66$ \\
\hline $30-34$ & $\left\{\begin{array}{l}\text { Claims } \\
\text { Persons }\end{array}\right.$ & $\begin{array}{r}15 \\
7\end{array}$ & $2 \cdot 14$ & $\begin{array}{l}5 \\
3\end{array}$ & $1 \cdot 67$ & $\begin{array}{l}20 \\
10\end{array}$ & $.2 \cdot 0$ \\
\hline $35-39$ & $\left\{\begin{array}{l}\text { Claims } \\
\text { Persons }\end{array}\right.$ & $\begin{array}{l}9 \\
7\end{array}$ & $1 \cdot 29$ & $\begin{array}{l}8 \\
5\end{array}$ & $1 \cdot 60$ & $\begin{array}{l}17 \\
12\end{array}$ & $1 \cdot 42$ \\
\hline $40-44$ & $\left\{\begin{array}{l}\text { Claims } \\
\text { Persons }\end{array}\right.$ & $\begin{array}{l}22 \\
17\end{array}$ & $1 \cdot 29$ & $\begin{array}{l}9 \\
6\end{array}$ & $1 \cdot 5$ & $\begin{array}{l}31 \\
23\end{array}$ & $1 \cdot 35$ \\
\hline $45-49$ & $\left\{\begin{array}{l}\text { Claims } \\
\text { Persons }\end{array}\right.$ & $\begin{array}{l}41 \\
21\end{array}$ & $1 \cdot 95$ & $\begin{array}{r}16 \\
8\end{array}$ & $2 \cdot 0$ & $\begin{array}{l}57 \\
29\end{array}$ & $1 \cdot 97$ \\
\hline $50-54$ & $\left\{\begin{array}{l}\text { Claims } \\
\text { Persons }\end{array}\right.$ & $\begin{array}{l}19 \\
15\end{array}$ & $1 \cdot 27$ & $\begin{array}{l}8 \\
5\end{array}$ & $1 \cdot 6$ & $\begin{array}{l}27 \\
20\end{array}$ & $1 \cdot 35$ \\
\hline $55-59$ & $\left\{\begin{array}{l}\text { Claims } \\
\text { Persons }\end{array}\right.$ & $\begin{array}{l}30 \\
13\end{array}$ & $2 \cdot 31$ & $\begin{array}{l}7 \\
3\end{array}$ & $2 \cdot 3$ & $\begin{array}{l}37 \\
16\end{array}$ & $2 \cdot 31$ \\
\hline $60-64$ & $\left\{\begin{array}{l}\text { Claims } \\
\text { Persons }\end{array}\right.$ & $\begin{array}{r}17 \\
7\end{array}$ & $2 \cdot 43$ & $\begin{array}{l}1 \\
1\end{array}$ & $1 \cdot 0$ & $\begin{array}{r}18 \\
8\end{array}$ & $2 \cdot 25$ \\
\hline $65+-$ & $\left\{\begin{array}{l}\text { Claims } \\
\text { Persons }\end{array}\right.$ & $\begin{array}{r}15 \\
6\end{array}$ & $2 \cdot 5$ & $\because$ & .. & $\begin{array}{r}15 \\
6\end{array}$ & $2 \cdot 5$ \\
\hline $\begin{array}{l}\text { Total } \\
\text { All Ages } \\
\text { from } 16\end{array}$ & $\left\{\begin{array}{l}\text { Claims } \\
\text { Persons }\end{array}\right.$ & $\begin{array}{l}246 \\
141\end{array}$ & $1 \cdot 74$ & $\begin{array}{r}132 \\
80\end{array}$ & $1 \cdot 65$ & $\begin{array}{l}378 \\
221\end{array}$ & $1 \cdot 71$ \\
\hline
\end{tabular}


caused and consequent loss of earnings in the family. The number of men who claimed benefit at any time since 1948 was 46.8 per cent. of all men between the ages of 16 and 69, while of the women between the ages of 16 and 64, $24 \cdot 5$ per cent. claimed benefit. It has to be remembered, however, that the women in the sample are married, and though a number of the older married women are at present insurable because of full-time or part-time employment, comparatively few of them have been in continuous employment and may not in the past have been eligible to claim for sickness or injury. Hence, the difference between male and female claims does not in any way represent a sex difference in sickness prevalence. Table XI (previous page) shows the age-sex distribution of the sickness and injury claims of the persons claiming; it indicates in each sex certain differences in claims at different ages, though it cannot be used to compare the two sexes.

Among young men the proportions rise progressively from the group aged 16 to 19 , reaching 50 per cent. in the group aged 25 to 29; above the age of 35 the proportions begin to rise again, and in the group aged 40 to 49 over 60 per cent. of all males have claimed benefit.

In Fig. 2, showing the age-sex distribution of persons who claimed sickness benefit, can be seen the different pictures presented by hospital-referred persons and by claimants for benefit. Among females, the high proportion of claims by young women under 25 is noticeable; at ages above this the insured population at any time since 1948 cannot be assessed and therefore the numbers claiming benefit cannot be related to the female population at risk.

These claims are by no means single occurrences. Many persons have claimed more than once, and some have made a sequence of claims for the same disabilty. Table XI illustrates the difference between sickness estimated by number of claims and sickness by number of claimants. Table XII (opposite) shows that the false picture of prevalence shown by the number of claims applies not only to the total volume of sickness but also to specific diseases, particularly the respiratory group. If prevalence were judged by the number of claims, the results would be an over-estimate of the prevalence of incapacitating respiratory disorders in the population.

These records show, as did hospital referrals, that a considerable proportion of the recorded sickness comes from a small proportion of the population, who have intermittent attacks and multiple sickness requiring assistance of some kind. The duration of disability shown by sickness claims indicates that the great majority of repiratory disorders which cause frequent claims are not of long duration. The diseases for which long-term incapacity is claimed include the ulcers, and the data reveal these as having considerable prevalence in this group.

The hospital-referred group also indicates a high prevalence of ulcers, rather higher than would have been thought from the number of sickness claims. It is surprising that for a condition such as this there should be any difference between the prevalence indicated by these two reliable and carefully-kept sets of records.

The ill-health described to us in the sample survey, in which most of the adult members of every household were interviewed, indicates a picture of disease prevalence 
TABLE XII

Persons Claiming Sickness Benefit and Number of Claims, 1948-51 (10 Per cent. Sample)

(Percentages are of population in related age groups)

\begin{tabular}{|c|c|c|c|c|c|c|c|c|c|}
\hline \multirow{2}{*}{\multicolumn{2}{|c|}{ Selected Disease Groups }} & \multicolumn{4}{|c|}{ Male } & \multicolumn{4}{|c|}{ Female } \\
\hline & & $\begin{array}{c}16-34 \\
\text { yrs }\end{array}$ & $\begin{array}{c}35-54 \\
\text { yrs }\end{array}$ & $\begin{array}{l}55 \text { and } \\
\text { over }\end{array}$ & $\begin{array}{l}\text { All ages } \\
\text { from } 16\end{array}$ & $\begin{array}{c}16-34 \\
\text { yrs }\end{array}$ & $\begin{array}{c}35-54 \\
\text { yrs }\end{array}$ & $\begin{array}{c}55 \text { and } \\
\text { over }\end{array}$ & $\begin{array}{l}\text { All ages } \\
\text { from } 16\end{array}$ \\
\hline Locomotor* & $\left\{\begin{array}{l}\text { Claims } \\
\text { Persons } \\
\text { Per cent. }\end{array}\right.$ & $\begin{array}{ll}8 & \\
6 & \\
& 4 \cdot 0\end{array}$ & $\begin{array}{l}12 \\
12 \\
11 \cdot 0\end{array}$ & $\begin{array}{l}12 \\
9 \\
17 \cdot 3\end{array}$ & $\begin{array}{l}32 \\
27 \\
\end{array}$ & $\begin{array}{l}5 \\
3\end{array}$ & $\begin{array}{l}7 \\
5 \\
\\
\end{array} 3 \cdot 8$ & - & $\begin{array}{r}12 \\
8 \\
\\
\quad 2 \cdot 3\end{array}$ \\
\hline Respiratory & $\left\{\begin{array}{l}\text { Claims } \\
\text { Persons } \\
\text { Per cent. }\end{array}\right.$ & $\begin{array}{l}31 \\
21 \\
\quad 14 \cdot 0\end{array}$ & $\begin{array}{l}31 \\
22 \\
20 \cdot 2\end{array}$ & $\begin{array}{l}25 \\
14 \\
26 \cdot 9\end{array}$ & $\begin{array}{l}87 \\
57 \\
18 \cdot 3\end{array}$ & $\begin{array}{l}31 \\
22 \\
\quad 14 \cdot 0\end{array}$ & $\begin{array}{r}11 \\
6 \\
\end{array}$ & $\begin{array}{l}3 \\
1\end{array}$ & $\begin{array}{ll}45 & \\
29 & \\
& 8 \cdot 5\end{array}$ \\
\hline $\begin{array}{l}\text { Ear, Nose, and } \\
\text { Throat }\end{array}$ & $\left\{\begin{array}{l}\text { Claims } \\
\text { Persons } \\
\text { Per cent. }\end{array}\right.$ & $\begin{array}{ll}10 & \\
8 & \\
& 5 \cdot 3\end{array}$ & $\begin{array}{l}5 \\
5 \\
4 \cdot 6\end{array}$ & - & $\begin{array}{ll}15 & \\
13 & \\
& 4 \cdot 2\end{array}$ & $\begin{array}{r}12 \\
6 \\
\quad 3 \cdot 8\end{array}$ & - & 1 & $\begin{array}{l}13 \\
7 \\
\end{array}$ \\
\hline Digestive & $\left\{\begin{array}{l}\text { Claims } \\
\text { Persons } \\
\text { Per cent. }\end{array}\right.$ & $\begin{array}{l}4 \\
4\end{array}$ & $\begin{array}{ll}5 & \\
5 & \\
& 4 \cdot 6\end{array}$ & $\begin{array}{l}2 \\
2\end{array}$ & $\begin{array}{ll}11 & \\
11 & \\
& 3 \cdot 5\end{array}$ & $\frac{2}{2}$ & $\begin{array}{l}5 \\
3\end{array}$ & - & $\begin{array}{ll}\frac{7}{5} & \\
& \\
& 1 \cdot 5\end{array}$ \\
\hline Ulcers & $\left\{\begin{array}{l}\text { Claims } \\
\text { Persons } \\
\text { Per cent. }\end{array}\right.$ & $\begin{array}{l}2 \\
2\end{array}$ & $\begin{array}{l}10 \\
5 \\
\end{array}$ & 2 & $\begin{array}{ll}14 & \\
9 & \\
& 2 \cdot 9\end{array}$ & $\begin{array}{l}1 \\
1\end{array}$ & 1 & - & 2 \\
\hline Skin Disorders & $\left\{\begin{array}{l}\text { Claims } \\
\text { Persons } \\
\text { Per cent. }\end{array}\right.$ & $\begin{array}{l}5 \\
5 \\
\\
\end{array} 3 \cdot 3$ & $\begin{array}{l}5 \\
5 \\
\end{array} 4 \cdot 6$ & $\begin{array}{l}2 \\
1\end{array}$ & $\begin{array}{ll}12 & \\
& 3 \cdot 5\end{array}$ & $\begin{array}{l}6 \\
3\end{array}$ & - & - & $\begin{array}{l}6 \\
3\end{array}$ \\
\hline Injuries & $\left\{\begin{array}{l}\text { Claims } \\
\text { Persons } \\
\text { Per cent. }\end{array}\right.$ & $\begin{array}{l}23 \\
21 \\
\\
14 \cdot 0\end{array}$ & $\begin{array}{l}12 \\
12 \\
11 \cdot 0\end{array}$ & $\begin{array}{l}14 \\
9 \\
17 \cdot 3\end{array}$ & $\begin{array}{l}49 \\
42 \\
\quad 13 \cdot 5\end{array}$ & $\begin{array}{l}7 \\
7 \\
\quad 4 \cdot 5\end{array}$ & $\begin{array}{l}3 \\
2\end{array}$ & $\begin{array}{l}2 \\
1\end{array}$ & $\begin{array}{l}12 \\
10 \\
\\
2 \cdot 9\end{array}$ \\
\hline $\begin{array}{l}\text { Gynaecological } \\
\text { Disorders }\end{array}$ & $\left\{\begin{array}{l}\text { Claims } \\
\text { Persons } \\
\text { Per cent. }\end{array}\right.$ & - & - & - & - & $\begin{array}{l}5 \\
4\end{array}$ & $\begin{array}{l}5 \\
4\end{array}$ & - & $\begin{array}{r}10 \\
8 \\
\quad 2.3 \\
\end{array}$ \\
\hline
\end{tabular}

* Includes rheumatism, lumbago, arthritis. See Table $\mathrm{X}$ for other categories of diseases.

different from that presented by official records of hospital-treated persons. The questions referred to sickness within the previous 2 months (i.e. since January, 1951), and to major illness in the previous year (i.e. since March, 1950); and questions concerning common ailments were limited to a few categories. The answers are summarized in Table XIII (overleaf). Many questions were not answered because people said, "I don't remember when it was", or described their feelings without knowing "what the trouble was".

In comparing the stated occurrences of sickness or doctor-visits-which informants specified quite definitely - with the dates officially recorded for these occurrences, we found many in which there were several months' difference. In one case of hospitalization described as being "a few months ago", we found that it had in fact occurred more than a year before the time given by the informant.

A considerable number of people described themselves as frequently suffering from colds or headaches, and respiratory complaints and "backaches" were also mentioned often. But the numbers "suffering from" a condition seemed to decrease as familiarity 
TABLE XIII

Child and Family Health, and Ailments of Individuals

Replies to Certain Questions asked in 133 Families

(a) FAMILY HEALTH

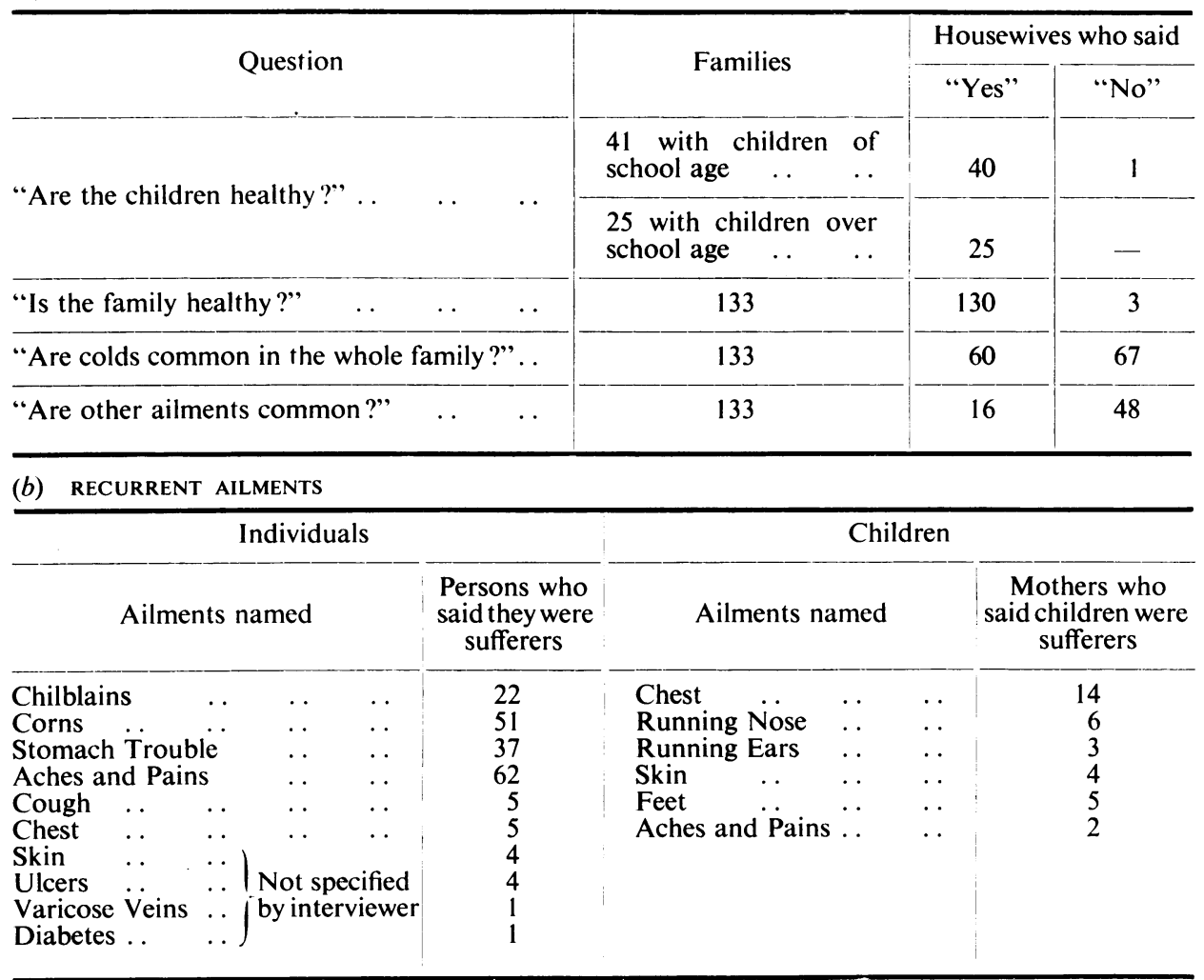

with the name of the condition decreased: in the initial "common ailment" question in which we named no specific illness, and also in the "recent illnesses" questions, a number of informants told us that they had had no ailment. When, however, various common conditions were named, informants often recalled being troubled by some of them. The prevalence of diseases "suffered" by our informants corresponded closely with fluency in sickness terminology. Whether this represents a real distribution of sickness in the population in general is debatable: in this sample it is certain that it did not, for we have objective data which contradict it from a number of sources trained in diagnosis.

The sickness described by informants as recently experienced or recurrently felt should correspond, to some extent, with two "stages" of ill-health in the community, namely, illness for which the sufferers consult the doctor and illness which the sufferers accept as chronic. The latter category, however, was described independently by the main doctors, and the picture was very different from that emerging from the household interviews. Of the 159 households in the "practice population", there were 
TABLE XIV

Recurrent Ailments in "Practice Population"

(a) Persons stated by Main Doctors to be Sufferers from one or more Recurrent or Chronic Complaints, by Age and Sex, April, 1951

\begin{tabular}{|c|c|c|c|c|c|c|c|c|}
\hline \multirow[b]{2}{*}{ Age } & \multirow{2}{*}{\multicolumn{2}{|c|}{ e Group }} & \multicolumn{2}{|c|}{ Male } & \multicolumn{2}{|c|}{ Female } & \multicolumn{2}{|c|}{ Both Sexes } \\
\hline & & & No. & $\begin{array}{l}\text { Per cent of } \\
\text { Practice } \\
\text { Population }\end{array}$ & No. & $\begin{array}{l}\text { Per cent of } \\
\text { Practice } \\
\text { Population }\end{array}$ & No. & $\begin{array}{c}\text { Per cent of } \\
\text { Practice } \\
\text { Population }\end{array}$ \\
\hline $\begin{array}{c}\text { Under } 1 . \\
1-4 \\
5-9 \\
10-14 \\
15-19\end{array}$ & $\begin{array}{l}\cdots \\
\cdots \\
\cdots \\
\cdots\end{array}$ & $\begin{array}{l}\ldots \\
\ldots \\
\ldots \\
\ldots\end{array}$ & $\begin{array}{l}\overline{12} \\
10 \\
23 \\
11\end{array}$ & $\begin{array}{l}-\overline{28 \cdot 6} \\
32 \cdot 3 \\
41 \cdot 1 \\
24 \cdot 4\end{array}$ & $\begin{array}{r}1 \\
9 \\
16 \\
25 \\
29\end{array}$ & $\begin{array}{l}-\overline{37 \cdot 5} \\
50 \cdot 0 \\
46 \cdot 3 \\
43 \cdot 9\end{array}$ & $\begin{array}{l}1 \\
21 \\
26 \\
48 \\
40\end{array}$ & $\begin{array}{l}-\overline{31 \cdot 8} \\
41 \cdot 3 \\
43 \cdot 6 \\
36 \cdot 0\end{array}$ \\
\hline $\begin{array}{l}20-24 \\
25-29 \\
30-34 \\
35-39 \\
40-44\end{array}$ & $\begin{array}{l}\ldots \\
\cdots \\
\cdots \\
\ldots\end{array}$ & $\begin{array}{l}\ldots \\
\ldots \\
\cdots \\
\ldots\end{array}$ & $\begin{array}{l}9 \\
9 \\
6 \\
9 \\
9\end{array}$ & $\begin{array}{l}23 \cdot 7 \\
25 \cdot 7 \\
28 \cdot 6 \\
60 \cdot 0 \\
40 \cdot 9\end{array}$ & $\begin{array}{r}18 \\
9 \\
5 \\
13 \\
20\end{array}$ & $\begin{array}{l}41 \cdot 9 \\
33 \cdot 3 \\
29 \cdot 4 \\
72 \cdot 2 \\
54 \cdot 1\end{array}$ & $\begin{array}{l}27 \\
18 \\
11 \\
22 \\
29\end{array}$ & $\begin{array}{l}33 \cdot 3 \\
29 \cdot 0 \\
29 \cdot 0 \\
66 \cdot 7 \\
49 \cdot 2\end{array}$ \\
\hline $\begin{array}{l}45-49 \\
50-54 \\
55-59 \\
60-64\end{array}$ & $\begin{array}{l}\cdots \\
\cdots \\
\cdots\end{array}$ & $\begin{array}{l}\cdots \\
\cdots \\
\ldots\end{array}$ & $\begin{array}{r}18 \\
6 \\
8 \\
5\end{array}$ & $\begin{array}{l}72 \cdot 0 \\
23 \cdot 1 \\
53 \cdot 3 \\
62 \cdot 5\end{array}$ & $\begin{array}{r}24 \\
9 \\
11 \\
10\end{array}$ & $\begin{array}{l}82 \cdot 8 \\
45 \cdot 0 \\
68 \cdot 8 \\
62 \cdot 5\end{array}$ & $\begin{array}{l}42 \\
15 \\
19 \\
15\end{array}$ & $\begin{array}{l}77 \cdot 8 \\
32 \cdot 6 \\
61 \cdot 3 \\
62 \cdot 5\end{array}$ \\
\hline $\begin{array}{l}65-69 \\
70-74 \\
75-79 \\
80 \text { or mor }\end{array}$ & $\begin{array}{l}\cdots \\
\cdots \\
\text { re }\end{array}$ & $\begin{array}{l}\cdots \\
\cdots \\
\cdots\end{array}$ & $\begin{array}{r}5 \\
3 \\
- \\
-\end{array}$ & $\begin{array}{c}55 \cdot 6 \\
- \\
-\end{array}$ & $\frac{1}{1}$ & $\begin{array}{l}- \\
-\end{array}$ & $\begin{array}{r}6 \\
5 \\
1\end{array}$ & $\begin{array}{c}54 \cdot 6 \\
55 \cdot 6 \\
- \\
-\end{array}$ \\
\hline All Ages. & . & . & 143 & $36 \cdot 1$ & 203 & $49 \cdot 3$ & 346 & $42 \cdot 8$ \\
\hline
\end{tabular}

(b) Households in Doctors' Practices containing one or more Sufferers from a Recurrent or Chronic Complaint, April, 1951.

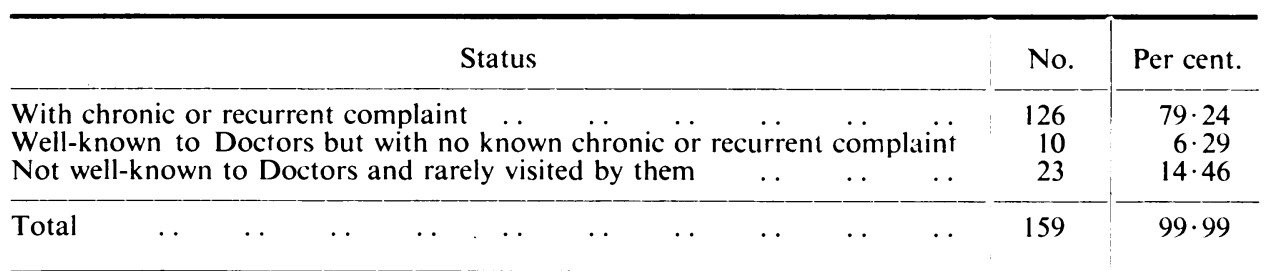

comparatively few for which the doctors had no knowledge of chronic condition or illness of any kind. Table XIV shows the number of households in which the doctors stated that one or more members had some recurrent or chronic complaint.

Apparently in this community almost every family has at least one member whom the doctors put into this category; in many cases the entire household is described by the doctors as suffering from chronic repiratory ailments or continuallyrecurring gastro-intestinal disorders. These conditions are rarely brought to the doctors for medical treatment, but are known to the doctors from visits to the houses when another member of the family was "really ill". 


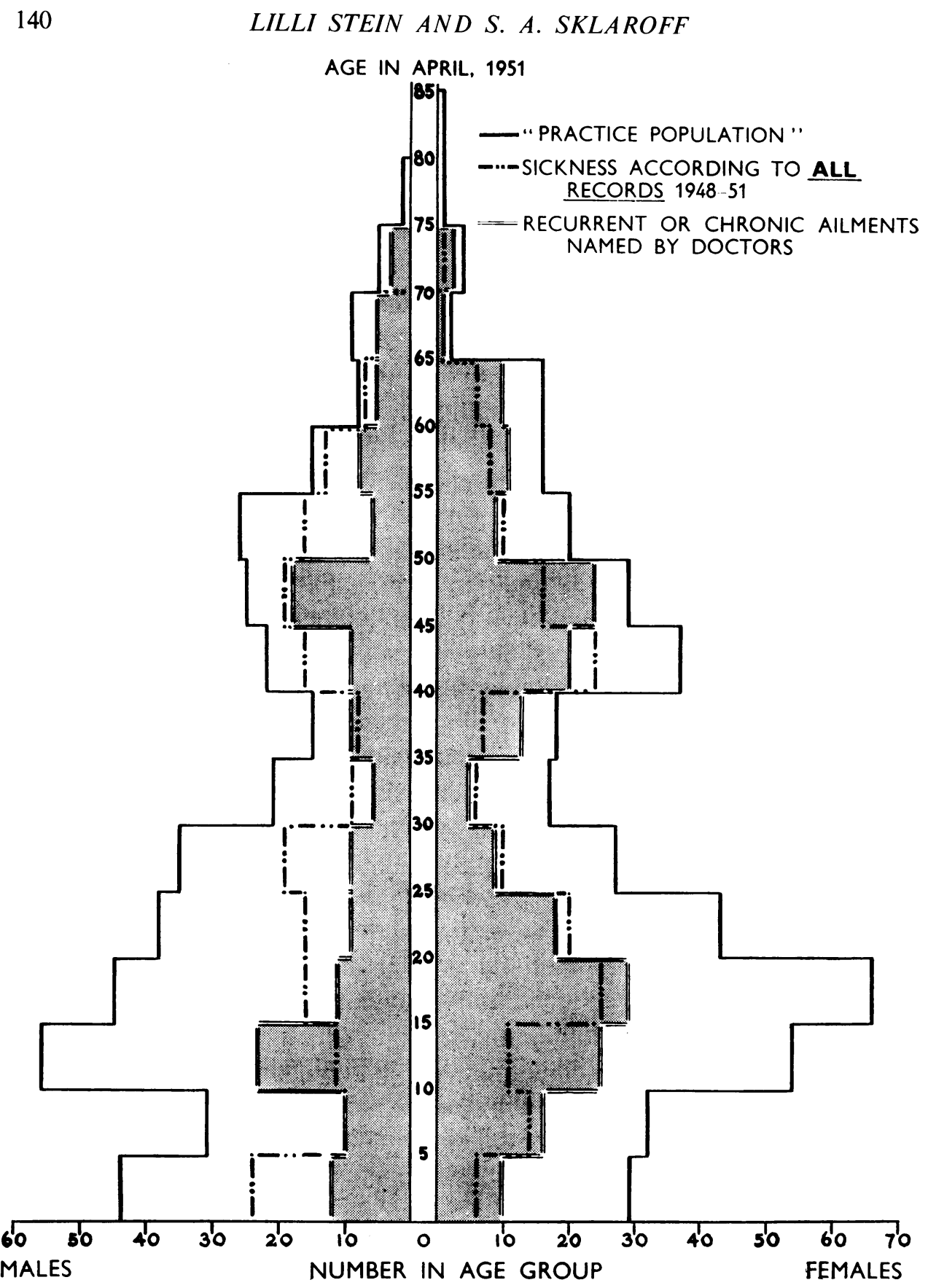


The age distribution of the persons whom the doctors described as having a recurrent ailment, depicted in Fig. 3, calls attention to the needs of an older population. The diseases which recur in this group are described in Table XV. Certain

TABLE XV

ReCURRENT Sickness

(a) In Families and Individuals in "Practice Population" (Selected Sickness Groups)

\begin{tabular}{|c|c|c|c|c|c|c|c|}
\hline \multirow{2}{*}{\multicolumn{4}{|c|}{ Type of Sickness }} & \multicolumn{3}{|c|}{ Persons with Sickness } & \multirow{3}{*}{$\begin{array}{c}\begin{array}{c}\text { Persons in Families } \\
\text { in which more than } \\
\text { one is Affected }\end{array} \\
99 \\
18\end{array}$} \\
\hline & & & & \multirow{2}{*}{$\begin{array}{c}\text { Male } \\
52 \\
21\end{array}$} & \multirow{2}{*}{$\begin{array}{c}\text { Female } \\
57 \\
21\end{array}$} & \multirow{2}{*}{$\begin{array}{c}\text { Both } \\
109 \\
42\end{array}$} & \\
\hline Respiratory & Disorders & & & & & & \\
\hline Tonsillitis & . & .. & . & 10 & 19 & 29 & 21 \\
\hline Dyspepsia & . & . & . & 9 & 5 & 14 & - \\
\hline Ulcers & . & . & .. & 17 & 5 & 22 & 5 \\
\hline Locomotor & .. & . & . & 7 & 11 & 18 & 8 \\
\hline Aches (Heac & d and Back) & .. & . & 10 & 11 & 21 & 8 \\
\hline Anaemia & . & .. & .. & 1 & 19 & 20 & 5 \\
\hline Neurosis an & d Anxiety & .. & . & 7 & 17 & 24 & 4 \\
\hline Skin Disord & lers & .. & . & 30 & 35 & 65 & 55 \\
\hline Gynaecologi & ical Disorde & .. & . & - & 14 & (14) & - \\
\hline Heart & .. & .. & .. & 7 & 6 & 13 & - \\
\hline
\end{tabular}

(b) In Men and Women in "Practice Population", by Age.

\begin{tabular}{|c|c|c|c|c|c|c|c|c|c|c|}
\hline Age Group. . & . & $\cdots$ & $\cdots$ & $\cdots$ & . & $15-24$ & $25-34$ & $35-44$ & $45-54$ & $\begin{array}{c}55 \\
\text { or more }\end{array}$ \\
\hline \multirow{2}{*}{ Respiratory } & \multirow{2}{*}{. } & \multirow{2}{*}{. } & & \multicolumn{2}{|c|}{ Minor $\left\{\begin{array}{l}\text { Male } \\
\text { Female }\end{array}\right.$} & $\begin{array}{l}11 \\
16\end{array}$ & $\begin{array}{l}2 \\
5\end{array}$ & $\begin{array}{l}5 \\
2\end{array}$ & $\begin{array}{l}3 \\
8\end{array}$ & $\begin{array}{l}1 \\
1\end{array}$ \\
\hline & & & & Other & $\left\{\begin{array}{l}\text { Male } \\
\text { Female }\end{array}\right.$ & $\overline{7}$ & 1 & $\begin{array}{l}3 \\
2\end{array}$ & $\begin{array}{l}5 \\
3\end{array}$ & $\begin{array}{l}5 \\
5\end{array}$ \\
\hline Dyspepsia .. & $\cdots$ & $\cdots$ & .. & $\ldots$ & $\left\{\begin{array}{l}\text { Male } \\
\text { Female }\end{array}\right.$ & 2 & $\overline{1}$ & $\underline{2}$ & $\begin{array}{l}2 \\
2\end{array}$ & $\begin{array}{l}3 \\
1\end{array}$ \\
\hline Ulcers & $\cdots$ & . & .. & .. & $\left\{\begin{array}{l}\text { Male } \\
\text { Female }\end{array}\right.$ & 2 & 5 & $\begin{array}{l}2 \\
3\end{array}$ & $\begin{array}{l}6 \\
1\end{array}$ & $\begin{array}{r}3 \\
-1\end{array}$ \\
\hline Anaemia .. & . & . & .. & .. & $\left\{\begin{array}{l}\text { Male } \\
\text { Female }\end{array}\right.$ & 二 & $\overline{4}$ & $\begin{array}{l}1 \\
7\end{array}$ & $\overline{4}$ & $\overline{2}$ \\
\hline Neurosis and An & xiety & $\cdots$ & .. & . & $\left\{\begin{array}{l}\text { Male } \\
\text { Female }\end{array}\right.$ & $\begin{array}{l}3 \\
3\end{array}$ & $\overline{2}$ & $\begin{array}{l}2 \\
4\end{array}$ & $\begin{array}{l}1 \\
6\end{array}$ & $\overline{2}$ \\
\hline Skin Disorders & . & .. & .. & .. & $\left\{\begin{array}{l}\text { Male } \\
\text { Female }\end{array}\right.$ & $\begin{array}{r}7 \\
16 \\
\end{array}$ & $\begin{array}{l}4 \\
1 \\
\end{array}$ & $\begin{array}{l}2 \\
5\end{array}$ & $\begin{array}{l}5 \\
2 \\
\end{array}$ & $\begin{array}{l}1 \\
3\end{array}$ \\
\hline Obesity & $\cdots$ & $\cdots$ & . & . & $\left\{\begin{array}{l}\text { Male } \\
\text { Female }\end{array}\right.$ & $\begin{array}{l}3 \\
4 \\
\end{array}$ & $\begin{array}{l}1 \\
2 .\end{array}$ & $\overline{3}$ & $\overline{8}$ & $\begin{array}{l}2 \\
4 \\
\end{array}$ \\
\hline Varicose Veins & . & $\cdots$ & $\cdots$ & $\cdots$ & $\left\{\begin{array}{l}\text { Male } \\
\text { Female }\end{array}\right.$ & 二 & 二 & $\overline{4}$ & $\begin{array}{l}1 \\
2 \\
\end{array}$ & 二 \\
\hline Gynaecological D & isord & & $\ldots$ & $\ldots$ & Female & 1 & 3 & 7 & 3 & - \\
\hline
\end{tabular}


ailments such as obesity, which did not appear in records at all, appear for the first time in these doctors' descriptions and are evidently prevalent. This volume of chronic sickness has been presented as such by doctors who know the people intimately and serve a large population, and it cannot be dismissed as imagined complaints expressed in interviews. Many of the chronic ailments are not minor conditions, and are considered by the doctors to be preludes to serious disability in the future. Yet the subjects are so used to living with their "trouble" that they hardly look on it as an illness requiring medical remedy, but regard themselves as healthy.

To define health is even more difficult than to define sickness. The underlying assumption seems to be that anyone who is not ill is healthy, that there are no grades of impaired health but only two sharp opposites. This basic assumption seems to be shared by official agencies and lay public alike, though the definitions applied in practice by official agencies are based on different criteria from those apparent in popular lay behaviour. Sickness as noted by any one agency has previously been described as "what is brought here and is eligible for assistance". So most health services in practice use the unstated definition of health as "any condition which does not absolutely necessitate intervention on our part". In the community, sickness is acknowledged by most people only if it is a conspicuous disability which differs in type or degree from habitual disability; it has previously been seen that in our sample the people did not over-claim nor over-report sickness which was certainly experienced. Similarly, in the community health is assumed to be any state which permits the continuance of habitual activities and occupations. For these reasons, among others, no adequate measure of health is available. At best, we can measure children's heights and weights, or the progress of infants and mothers, and interpret these as indices of health.

TABLE XVI

Height and Weight of Primary School Children

\begin{tabular}{|c|c|c|c|c|c|c|c|}
\hline \multicolumn{5}{|c|}{10 per cent. Sample (121 children), April, 1951} & \multicolumn{3}{|c|}{ City Averages, $1948-50$} \\
\hline$\underset{\text { Age }}{* \text { Approximate }}$ & Measurement & Sex & Mean & $\begin{array}{l}\text { Standard Error } \\
\text { of the Mean }\end{array}$ & 1948 & -49 & $1949-50$ \\
\hline \multirow{2}{*}{$\begin{array}{c}\text { *5-Year-Old } \\
(60)\end{array}$} & $\begin{array}{c}\text { Height } \\
\text { (in.) }\end{array}$ & $\begin{array}{l}\text { Boys } \\
\text { Girls }\end{array}$ & $\begin{array}{l}42 \cdot 58 \\
41 \cdot 77\end{array}$ & $\begin{array}{l}\cdot 382 \\
\cdot 414\end{array}$ & \multirow{2}{*}{ *Infants } & $\left(\begin{array}{l}42 \cdot 72 \\
42 \cdot 26\end{array}\right.$ & $\begin{array}{l}42 \cdot 47 \\
42 \cdot 14\end{array}$ \\
\hline & $\begin{array}{l}\text { Weight } \\
\text { (lb.) }\end{array}$ & $\begin{array}{l}\text { Boys } \\
\text { Girls }\end{array}$ & $\begin{array}{l}42 \cdot 02 \\
41 \cdot 31\end{array}$ & $\begin{array}{l}.909 \\
.932\end{array}$ & & $\begin{array}{l}42 \cdot 23 \\
41 \cdot 01\end{array}$ & $\begin{array}{l}42 \cdot 55 \\
41 \cdot 21\end{array}$ \\
\hline \multirow{2}{*}{$\begin{array}{c}\text { †9-Year-Old } \\
\text { (61) }\end{array}$} & $\begin{array}{c}\text { Height } \\
\text { (in.) }\end{array}$ & $\begin{array}{l}\text { Boys } \\
\text { Girls }\end{array}$ & $\begin{array}{l}50 \cdot 74 \S \\
50 \cdot 69\end{array}$ & $\begin{array}{l}.422 \\
.365\end{array}$ & & $\begin{array}{l}51 \cdot 53 \\
51 \cdot 03\end{array}$ & $\begin{array}{l}51 \cdot 59 \\
51 \cdot 25\end{array}$ \\
\hline & $\begin{array}{c}\text { Weight } \\
\text { (lb.) }\end{array}$ & $\begin{array}{l}\text { Boys } \\
\text { Girls }\end{array}$ & $\begin{array}{l}61 \cdot 38 \S \\
60 \cdot 57\end{array}$ & $\begin{array}{l}1 \cdot 229 \\
1 \cdot 034 \\
\end{array}$ & & $\begin{array}{l}63 \cdot 92 \\
61 \cdot 23 \\
\end{array}$ & $\begin{array}{l}64 \cdot 04 \\
62 \cdot 75 \\
\end{array}$ \\
\hline
\end{tabular}

* "Infants" include children aged 5 and usually under 6 . In our sample, most of the children's heights and weights were recorded some months after their fifth birthday: some were recorded after their sixth birthday.

$t$ "9-year-old" children's heights and weights include those of children aged 9 and usually under 10 . In our sample, a number of the heights and weights were recorded after the 10 th birthday.

$\ddagger$ The significance of the difference between a sample mean and the corresponding city average is judged according to the standard error of the sample mean. If the difference between mean and city average is more than twice the standard the standard error of the sample mean. If the difference between mean and city average is more tha
error, the probability that this is due to chance is less than 1 in 20 : this is taken to be significant.

$\$$ Mean height and weight of the 9-year-old boys in the sample are significantly below the city average. The means for girls of this age are also low. 
The children in our sample were examined by their school doctors at very different times, and therefore the school medical records of the children are not quoted in detail. But comparable items in the records are quoted, and Table XVI shows that, though the 5-year-old children were similar both in height and in weight to the city average, the 9-year-old children were below the city average. In the boys, the difference in height was just significant and the difference in weight statistically very significant.

The city notifications of infectious diseases are restricted to certain categories of children, and can be used neither for estimating prevalence nor for comparing with sample figures. Table XVII shows these notifications during 1948-51 for the sample children in the three local primary schools, and shows also the infectious diseases recorded by the doctors during the same period. The school records of infectious diseases are not comparable, for they relate to the entire life of the children: from these it appears that the great majority of the school children in the sample have had measles before the age of five. Also, the mothers' answers to the survey questionnaire corresponded closely to the school record figures for measles, whooping-cough, and chicken-pox. For scarlet fever, however, the mothers' answers showed a rather higher incidence than was noted in the school records.

TABLE XVII

INFECTIOUS DISEASES

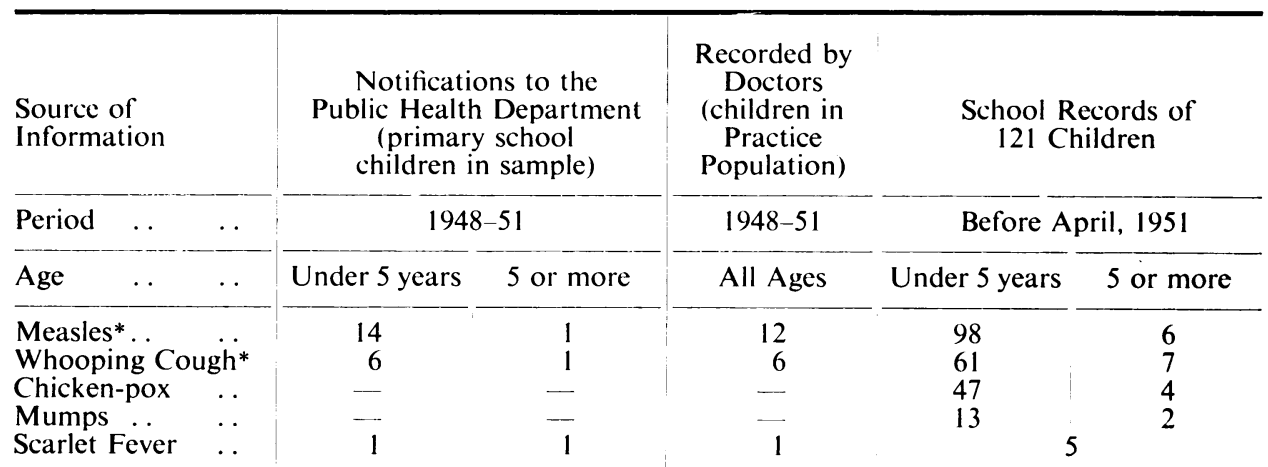

* Measles (and whooping-cough, until recently) is compulsorily notifiable in the city if the child is under 5 years of age and is the first case in the household.

Most of the primary school children were also carefully examined by our own dentist; of the 107 children whose teeth were fully inspected, 36 were diagnosed as having early parodontal disease. Moreover, the dentist's estimate of oral hygiene gave nearly 20 per cent. as neglected and only 42 per cent. as good. The incidence of dental caries among young children is very high (Table XVIII, overleaf). Only 32 per cent. had caries-free permanent teeth, while the other 68 per cent. had a least one carious permanent tooth and many required four to eight teeth to be filled. The deciduous teeth were even more carious, less than 30 per cent. of the children having sound ones. It may be of interest to compare these findings with the latest City Report on School Health, in one section of which it is stated that 5.37 per cent. of the infant boys and $6 \cdot 24$ per cent. of the infant girls examined were considered to have 
TABLE XVIII

Results of Dental Examination of 114 Primary School Children

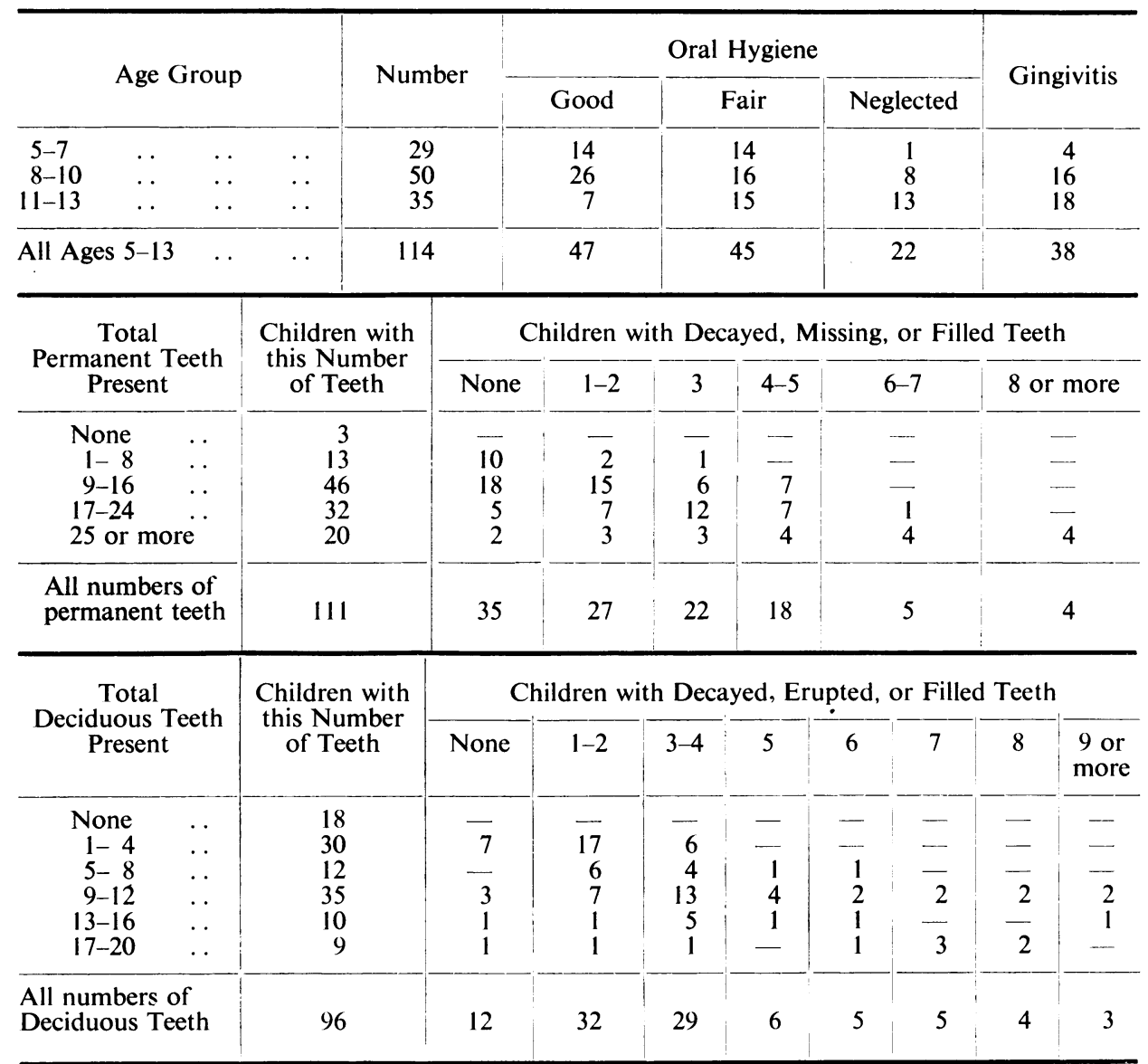

mouth and teeth unhealthy. The figures for the 9 -year-old boys and girls were $6 \cdot 52$ and 5.06 per cent. respectively. In another section it is reported that 76 per cent. of the 5 to 17 -year-old children who were systematically examined were discovered to require dental treatment.

The School Health Service dentists visit schools as regularly as possible, and inform the parents of children whose teeth need attention by sending them a "consent card" offering treatment. Some parents indicate refusal by writing "teeth healthy" or "no fillings required" on these cards. Such are the layman's ideas of dental health as compared with the standards of dentists.

Ideas on what constitutes health were revealed also in answers to questions in the household interviews. Certainly the childhood infections were not mentioned unless specifically named by interviewers. The familiarity of childhood illnesses is such that they seem to be regarded as merely minor disturbances incidental to the growth 
of the child. But other conditions, such as running ears, skin troubles, or continual colds, were also considered compatible with perfect health. Of the housewives who were asked whether theirs was a healthy family, almost all answered vigorously in the affirmative; a very few qualified their affirmative a little, and only one suggested a negative answer. Similarly very few said that they bought patent medicines, but, when the general question was followed up by questions on aspirins, salts, ointments, and so on, it appeared that in four out of five households some form of laxative was bought. Aspirins and headache powders ranked nearly as high (Table XIX).

Laxatives seem to be given to entire families of children automatically as "health care" in the traditional Saturday night dose. Persons of all ages, but particularly older men, stated that they regularly took laxatives twice a week or more.

TABLE XIX

Patent Medicines Bought and Used by 5 per cent. Of Households in Estate (109 Families)

\begin{tabular}{|c|c|c|c|c|c|c|c|c|}
\hline \multirow[t]{2}{*}{ (a) } & Type of Patent Medicine & Laxatives* & \multicolumn{2}{|c|}{ Salts* } & Aspirint & Ointment & $\begin{array}{l}\text { Cough } \\
\text { Mixture }\end{array}$ & $\begin{array}{c}\text { Total } \\
\text { Families }\end{array}$ \\
\hline & No. of Households & 42 & \multicolumn{2}{|c|}{41} & 74 & 12 & 27 & 109 \\
\hline \multirow[t]{2}{*}{ (b) } & No. of Medicines Bought & 0 & 1 & 2 & 3 & 4 & 5 & $\begin{array}{l}\text { Total one } \\
\text { or more }\end{array}$ \\
\hline & No. of Households & 22 & 27 & 21 & 22 & 13 & 4 & 87 \\
\hline
\end{tabular}

* Laxatives (including Salts) were taken occasionally by 17 persons, and regularly by 89 (information regarding children was given by the mother). The approximate age distribution of the 89 was: Children, 31; Women, 14 aged under 40 , 15 aged 40 and over; Men, 9 aged under 40,20 aged 40 and over.

$\dagger$ Aspirins were taken occasionally by 20 persons, and regularly by 26 (of the total 46, 18 were young women).

Several other questions touched on attitudes to health and practices in health care. The answers were too diverse for classification, but they revealed again the dichotomy between popular concepts of health and sickness. Just as official agencies, both in theory and in practice, make a distinction between sickness services and health services, a distinction which is reflected in their records, so the habits of the community reflect the many divisions which exist between the various aspects of sickness, and differentiate even further between any of these aspects and the standard of health.

The various records have already shown how the different aspects recognized as sickness by the different agencies can produce a picture of prevalence which may be not only false but misleading. Similarly our household interviews showed that these divisions between aspects of sickness led to people becoming involved with one hospital after another: the number of agencies with which many of the households have been in contact is quite startling. For many families the passage from one hospital to another department, thence to a clinic, and perhaps again to a hospital, must have caused much distress and disturbance.

The family answers as well as the records underestimate the prevalence of certain diseases and overestimate others. Certain diseases have a higher prestige in conversation and certain recurrent ailments are never mentioned. Prominent among these are the "women's complaints" (mentioned by one informant only and "not 
remembered" by other informants even after prompting); neither does dysmenorrhea appear in any record at all: yet it is known to be prevalent in all communities, and certainly in this group. A number of women discreetly mentioned "monthly" aspirins in answer to the "patent medicine" questions. To some extent mention of intestinal or gastric complaints was also evaded, and ulcers, though quite "respectable" were mentioned by only four of the 21 sufferers.

Manifestly the dichotomy between the concept of health and that of sickness exists in official as well as in popular thought and practice; yet it is a different dichotomy. Official concepts seem to be based not on medical or welfare standards but on the involvement of the agency and the eligibility of the applicant for benefit. The community also judges health and sickness according to non-medical criteria. Attitudes to sickness seem to depend on what is "normal" by group standards and experience, and on what might appear as conspicuous in the group. In addition, the family tends to judge sickness by the conspicuous departure of an individual from familiar disability or habitual ailment. Thus both group and family norms influence the conduct of people faced with unusual illness; and also, the answers given to interviewers are based on the family attitude to "strangers". Group attitudes to health are more nebulous: health has prestige in this community, particularly in the verbal response to outsiders. Thus the criteria of health are completely different from the criteria of sickness. Being healthy depends on group norms of experience and approval as well as on physical fitness. Judgments of health are based also on personal norms of habit, of accepted disability, of the capacity to function in household or occupational routine, and of the frequency with which illness interrupts such a state of health.

It is not surprising that the popular attitude to sickness should be so far separated from the facts of disability. Most disabilities in this group are of the type which advance gradually and to which the sufferers become adapted. Moreover, there is no agency, either in this estate or in most other communities, which caters for the "not fully healthy" by offering remedial services which do not disrupt daily life or earning capacity. For the person who needs treatment but who is not conspicuously ill, regular remedial measures which can be fitted into normal working life are almost impossible to obtain. It is natural therefore that most people continue to live with their disabilities, continue to adapt themselves for as long as possible while those disabilities do not become so conspicuous that they demand action. The popular concept of sickness must inevitably be influenced by the financial difficulties of being unfit and by the remoteness of convenient remedy. If health services do not offer suitable provision for those in a state of impaired health, it is to be expected that the ailing will not regard themselves as sick.

\section{Discussion}

The measurement of sickness in the population is the indispensable foundation for the proper provision for future needs, and the measurement of the intermediate stages between sickness and full health is equally essential for planning new services. 
The actual needs of a community are often not revealed until some provision for treatment or for health promotion has become established. Provision made on the basis of past recorded sickness only can lead to serious under-estimation of the extent to which new services will be used.

But measurement of sickness and of degrees of unfitness cannot be attempted at national or large-scale levels unless very full local knowledge is already available. Indices of health or sickness have little meaning if they are only averages for large numbers of people who have no common life and environment. The measures of health and sickness must be evolved in relation to a community group and its characteristicswhether the community is large or small, stable or changing, what population composition it has, whether the married women work, whether the different generations are crowded together in the same households, and whether local social and economic conditions encourage certain ailments. Such characteristics form only part of the required knowledge. Equally needed is knowledge of endemic or chronic diseases, of attitudes to sickness and the use made of provided services, of attitudes to health and the possibilities of health education or promotion, of the working hours and leisure habits against which the provision of remedial treatment might be planned.

The problem of obtaining measurements which have meaning is similarly bound up with the attitudes and standards of the doctors, specialists, and officials who have authority in the group. "Doctor norms" influence both the behaviour of a group in its use of medical services in cases of "real illness" and the possibility of measurement from the records kept. Even the current definitions of health and the recognition of sickness depend on medical attitudes and advances: they form the background against which the prestige of health can change, against which some illnesses develop high standing whilst others become almost taboo.

Thus measurement is related not only to sickness experience and the difficulties of defining and recording it, but also to attitudes and social characteristics. The future needs of a group are also related to these circumstances and characteristics, and national estimates of needs can only be based on intensive local studies. The demographic structure of any group is the framework in which the future population develops, and the conditions of the present foretoken future socio-medical needs.

In the community from which our sample was drawn these points are amply illustrated. Group standards of "normal" health effect recognition of sickness and action taken. Equally they influence accuracy of measurement, particularly that obtained by survey interviewing when answers to questions are biased by attitudes to interviewers as well as by interpretations of sickness symptoms and labels. Official records give measurements biased in other directions, for they measure not sickness but those conditions which are conspicuous and eligible from their particular standpoint. One cannot say that the needs of this community are underprovided, for no needs are expressed: yet real needs are seen when the picture of composite sickness, of chronic ailments, and of impaired health is examined.

The present age-structure of this group and the social and economic difficulties of the elderly and of the widowed or separated women disclose some of its special 
needs. The number of middle-aged and elderly people referred to hospitals, the high incidence of respiratory and gastro-enteric diseases, and of chronic sickness, all bear witness to the need for local provision directly related to local ill-health.

The age-structure and housing circumstances of this group must lead to an even greater need of medical care in the future, as the young married couples find houses of their own outside the estate, and increasing numbers of elderly couples or widowed persons are left as sole occupants. The higher proportions of elderly people will in themselves necessitate greater provision for this category. The elderly may be permitted to take lodgers in order to fill the house and to supplement their pensions: on the other hand, the houses may be required for younger families whose need for re-housing is great. Priorities at present include some due to illness: the estate already contains a number of families re-housed owing to overcrowding associated with illness. If this tendency continues, the population will come to contain even more families with known chronic or infectious disease.

Another problem is that of three-generation households in which young couples are bringing up their babies. The young mother is inevitably influenced by living in the house of her mother or mother-in-law. To what extent the attitudes of the grandparent generation would affect the young mother if she were in her own home one cannot say: it is certain that when she has her first child in the maternal home the dominant influence is that of the older woman who has "brought nine children into the world, my girl". Attitudes to health and ante-natal care, to infant feeding, and to "dosing" of children are in many households those of the grandparent generation.

From the material collected here, certain conclusions are clearly indicated:

(1) The problems of measuring sickness and of assessing present and future needs in the context of the actual group circumstances require:

(a) Definitions of sickness and systematic classification of "stages" of health from which the composite "total" sickness in the group can be compounded;

(b) Intensive study of the group and intimate knowledge of the many sides of group life and standards, so that the attitudes and behaviour in relation to ill-health can be understood.

(2) Sickness records for the unit of intensive study, the small community group, should be built up on the basis of the household rather than of the individual. The main doctors on this estate have long since arrived at the practice of keeping a family index, from their experience of the best and most relevant method of working in the community. It may be noted also that the non-medical agencies which give financial or social assistance keep sickness data for the whole family together and see sickness in any member of the family as affecting the family welfare.

(3) The classification system of stages of "impaired health" is suggested as one which can start with the person experiencing disability and can take in each stage of ill-health from that point. The first stage of "impaired health" is that in which minor disability is experienced intermittently, and such minor disability will often not be seen by a doctor: at present it can only be discovered by surveys and family interviews. Nor may the next stage, that of recurring disability, be brought to a doctor, though on the other hand, the stage of ill-health which is brought to the doctor may be much 
less serious. It is evident that a systematic classification must be worked out, and that co-operation between health workers' methods of recording stages of impaired health must be constantly maintained, if community sickness is really to be measured.

But the present knowledge of group differences in respect of sickness attitudes and actions is quite inadequate for any systematic classification to be established. Many intensive studies of many groups in different localities are required if such knowledge of the volumes and types of sickness is to become available.

Certain ailments in particular seem to require fuller study and clearer definition. For example, many people were described by the doctors on the estate as "neurotic", yet the judgments on which such descriptions were based varied greatly.

From the composite picture of sickness in the sample the present state of health of this estate community can be assessed. It seems probable that some of the health problems are associated with the population structure which has developed from the originally-rehoused families and from the outward migration of the children. The wisdom of "setting up a community" by filling a large number of newly-built houses with a very selected group of families is debatable, since in relieving one urgent need, it may cause serious socio-medical problems to arise in the future.

These matters are by no means of local importance only. The housing estates in Britain are numerous, and many of them have grown up like this one-by initial settlement at one period in time, by the selection of a definite category of the general population, by location at some distance from the centre of the city, of families of approximately similar size and age, in houses uniformily built and equipped. With the present need for houses still more "estates" may be created. If local authorities can only take future population developments into account when these estates are peopled, the socio-medical difficulties which can evolve in a selected population after a period of 10 to 20 years may be avoided.

\section{SUMMARY}

(1) A socio-medical survey was made of a housing estate where families were re-housed 16 years ago. The survey was undertaken as a pre-pilot enquiry in connection with a long-term research programme for the study of a "social disease". The need to study the social group in which a disease occurs and spreads, rather than the "diseased" and "controls", is emphasized.

(2) Four aspects of community life-housing occupancy, general health experience, food habits, and leisure activities-were investigated. The information obtained in household interviews was related to the data obtained from all possible records. One aim of the enquiry was to compare and appraise the different pictures of ill-health as described by different records or by sample survey interviewing.

(3) The demographic structure differs from that of the city population as a whole. The age distribution is bi-modal, the majority of the main householders being elderly. There are marked deficits in the age-groups under 10, and between 25 and 39 .

(4) The structure of the households seems to be associated with both the original selection of the families and the present housing shortage. More than one quarter 
of the households contain, in addition to the main family, a sub-family of a young married son or daughter. More than 18 per cent. are three-generation households.

The resulting demographic problems are indicated. The developments to be expected as young couples find houses outside the estate indicate still greater problems in the future.

(5) The levels of sickness as estimated from each set of records are described, and compared with each other and with the picture obtained from the survey interviews. The differences between the proportions of people absent from work because of illness and the proportions referred to hospital are greatest for men aged 20 to 29 and women aged 20 to 24 , and are also large in other age-sex groups.

The proportions of people referred to hospital, when compared with those claiming sickness benefit, indicate that absence from work owing to illness is not excessive.

(6) The diseases prominently represented in the different records differ somewhat, but injuries and respiratory disorders form a considerable proportion of each.

(7) The descriptions of personal and family health given in the survey interviews indicate that most families do not regard their ailments as "illness" except when they cause conspicuous disturbance. The reliability of sickness estimates based on survey interviews is questionable, not only because of memory difficulties, but more noticeably because of divergencies in community definitions of sickness and differences in group perceptions of "conspicuous sickness".

(8) Additional data are presented on the incidence of recurrent and chronic ailments as observed by the doctors. In all age-sex groups the proportions suffering from recurrent conditions are considerable, and increase with age. Nearly 80 per cent. of the sample households contain at least one person with recurrent chronic ailment.

(9) The high incidence of respiratory disorders is also seen in the recurrent ailments. Certain other conditions especially skin diseases in both sexes, and in anaemia, neuroses, and obesity in women, are more prevalent than the records show.

(10) The health of the primary school children is considered in terms of heights and weights, childhood infectious diseases, and condition of teeth. The incidence of dental caries is very high, even in the permanent teeth of young children; only oneeighth of the children had sound deciduous teeth.

(11) The dichotomy between the concept of health and the concept of sickness is apparent both in official and in popular thought. Measurements of sickness from administrative records cannot be regarded as indices of health.

(12) Measurements of sickness in different communities may differ because of their relation to group characteristics and attitudes, and can only be interpreted in the light of detailed knowledge of local norms. The accumulation of such local knowledge requires intensive studies of many other small communities.

(13) Some unified system of sickness classification is needed to relate the different concepts of ill-health to each other and make all records of sickness contiguous and comparable. A common set of definitions should include the first stage of "impaired health" from its occurrence in the individual, and embrace the various stages of ill-health as treated by medical and other agencies. 
(14) There are a number of socio-medical and health problems in this housingestate community. The significance of these findings needs to be considered in relation to the probable increase in the number of re-housed communities in the future.

It is with pleasure that we express our deep gratitude to Professor F. A. E. Crew for his vision in the initiation of this work and his encouragement in its execution. Grateful thanks are also offered to the many national and local authorities for their ready co-operation, to the Edinburgh Public Health Department and its staff for their generous assistance, to the Health Visitors for their untiring energy, to the doctors for their guidance and consistent interest, to the hospitals whose records were made available, and to all the people whose work went into this survey. 